WSRC-TR-2000-00182

\title{
Metallurgical Laboratory (MetLab) Treatability Study: An Analysis of Passive Soil Vapor Extraction Wells (PSVE) June 2000 Update (U)
}

\author{
B. D. Riha \\ J. Rossabi \\ W. K. Hyde
}

Westinghouse Savannah River Company

Savannah River Site

Aiken, SC, 29808

Prepared for the US Department of Energy under Contract DE-AC09-96SR18500 
This document was prepared in conjunction with work accomplished under Contract No.

DE-AC09-96SR18500 with the U.S. Department of Energy.

\section{DISCLAIMER}

This report was prepared as an account of work sponsored by an agency of the United States Government. Neither the United States Government nor any agency thereof, nor any of their employees, makes any warranty, express or implied, or assumes any legal liability or responsibility for the accuracy, completeness, or usefulness of any information, apparatus, product or process disclosed, or represents that its use would not infringe privately owned rights. Reference herein to any specific commercial product, process or service by trade name, trademark, manufacturer, or otherwise does not necessarily constitute or imply its endorsement, recommendation, or favoring by the United States Government or any agency

thereof. The views and opinions of authors expressed herein do not necessarily state or reflect those of the United States Government or any agency thereof.

This report has been reproduced directly from the best available copy.

Available for sale to the public, in paper, from: U.S. Department of Commerce, National Technical Information Service, 5285 Port Royal Road, Springfield, VA 22161, phone: (800)

553-6847, fax: (703) 605-6900, email: orders@ntis.fedworld.gov online ordering: http://www.ntis.gov/ordering.htm

Available electronically at http://www.doe.gov/bridge

Available for a processing fee to U.S. Department of Energy and its contractors, in paper, from: U.S. Department of Energy, Office of Scientific and Technical Information, P.O. Box 62, Oak Ridge, TN 37831-0062, phone: (865 ) 576-8401, fax: (865) 576-5728, email: reports@ adonis.osti.gov 


\section{Contents}

EXECUTIVE SUMMARY ............................................................................................... 1

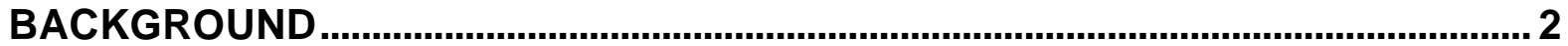

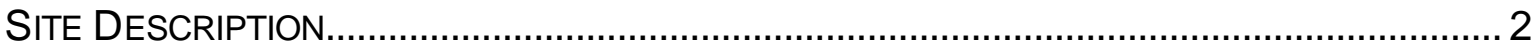

PREVIOUS CHARACTERIZATION EFFORTS ............................................................... 2

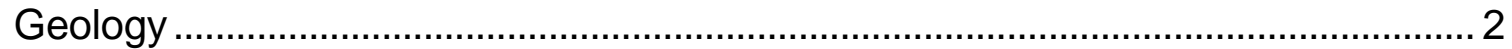

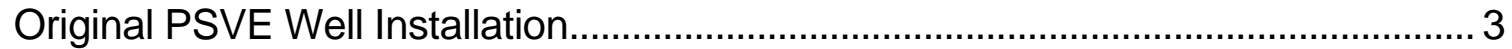

TECHNOLOGY DESCRIPTION - BAROMETRIC PUMPING ................................................... 4

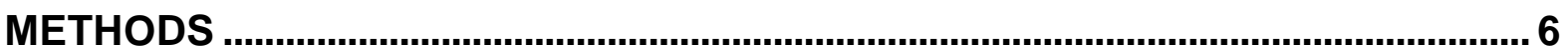

ADDITIONAL CHARACTERIZATION WORK IN FYO0.......................................................... 6

WELL VAPOR SAMPLING AND ANALYSIS METHODS ................................................... 6

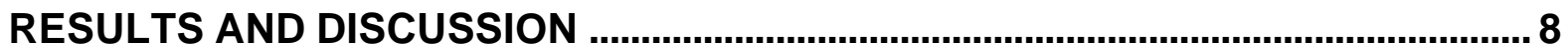

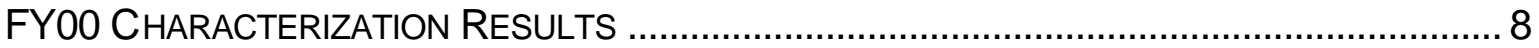

WELL FLOW RATES AND VAPOR CONCENTRATION.................................................. 10

FLOW CONTROL ENHANCEMENT OF MASS REMOVAL ............................................... 19

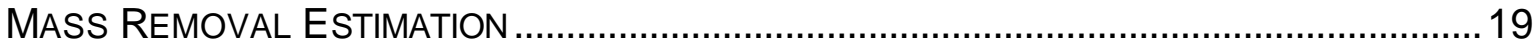

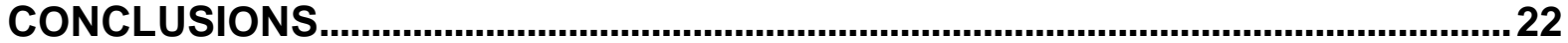

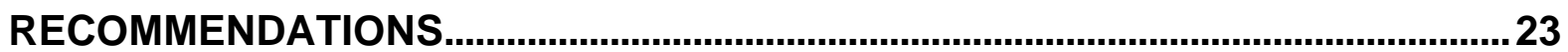

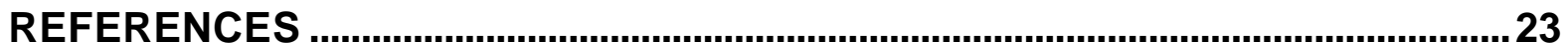

APPENDIX A - WELL VAPOR CONCENTRATIONS................................................... 24

APPENDIX B - CPT LOGS ........................................................................................... 32

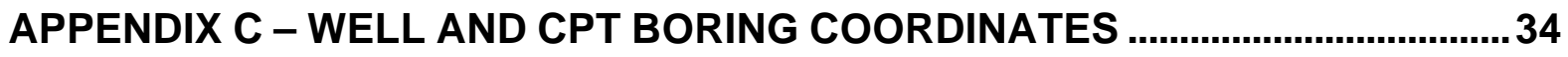




\section{List of Tables}

Table 1 - MLBB-022 Soil Gas Characterization Results ............................................... 8

Table 2 - MLBB-023 Soil Gas Characterization Results

Table 3 - Trend Data Information and Average Freon-113 Concentrations for MetLab Vadose Zone Plume .....

Table 4 - Fitted PCE Concentration Data and Estimated Mass Removed by Well for the MetLab Vadose Zone Plume.

Table 5 - Fitted TCE Concentration Data and Estimated Mass Removed by Well for the MetLab Vadose Zone Plume.

\section{List of Figures}

Figure 1 - MetLab Site Map. 3

Figure 2 - CPT Soil Classification for MLBB-022 and MLBB-023 .............................. 9 Figure 3 - PCE Well Vapor Concentration Trends for MetLab Vadose Zone Plume... 11 Figure 4 - TCE Well Vapor Concentration Trends for MetLab Vadose Zone Plume ... 12 Figure 5 - TCE Soil Gas Plume Contours for MetLab Vadose Zone, ppmv (6/98 and $1 / 99)$

Figure 6 - TCE Soil Gas Plume Contours for MetLab Vadose Zone, ppmv (6/99 and $1 / 00)$

Figure 7 - TCE Soil Gas Plume Contours for MetLab Vadose Zone, ppmv (6/00) ...... 15 Figure 8 - PCE Soil Gas Plume Contours for MetLab Vadose Zone, ppmv (6/98 and $1 / 99)$

Figure 9 - PCE Soil Gas Plume Contours for MetLab Vadose Zone, ppmv (6/99 and $1 / 00)$

Figure 10 - PCE Soil Gas Plume Contours for MetLab Vadose Zone, ppmv (6/00) ... 18

Figure 11 - Cumulative Mass Removed for MetLab Vadose Zone Plume. 21 


\section{Executive Summary}

The passive soil vapor extraction (PSVE) system at the MetLab of the Savannah River Site has been operating since May 1998. The results to date on the treatability study indicate the technology is performing well. Well concentrations are decreasing and contour maps of the vadose zone soil gas plume show a decrease in the extent of the plume. In the 2 years of operation approximately 270 pounds of chlorinated organic contaminants have been removed by natural barometric pumping of wells fitted with BaroBall valves (low pressure check valves).

Additional characterization was completed in FY00 to evaluate the concentration of the soil gas plume on the south and west sides of the well field. One well was installed and two soil gas pushes were completed. The maximum soil gas concentrations observed from both CPT soil gas pushes were 3.0 ppmv PCE, 3.5 ppmv TCE, and 4.5 ppmv Freon 113. Additional wells were not installed due to the low concentrations. Based on the new characterization data and the monitoring results from the existing wells, the current well system adequately bounds the soil gas plume.

At the current fitted removal rates all but 5 of the wells will be below 5 ppmv by the end of 2001. Projecting the concentration trends, all the wells will be below 5 ppmv by $1 / 2005$. The initial source mass estimate is $170 \mathrm{lbs}$ TCE and $250 \mathrm{lbs}$ PCE. These masses correspond to approximately 14 gallons of TCE and 18 gallons of PCE that will be removed from the subsurface at the site.

Mass removal during this time frame is primarily attributed to residual contamination in the coarse grained material and contaminant mass transfer from the finer grained zones to coarse zones where the majority of the PSVE flow is achieved. Removal from the fine grained sediments will be limited by the mass transfer from these zones to the coarse grained zones.

The PSVE system has required minimal operating and maintenance costs and can be expected to operate continuously for the life span of the remediation with little or no intervention. All of the vadose zone extraction wells installed can also be used with an active vapor extraction system.

The PSVE system is performing well in a cost-effective manner. It is recommended that this system be allowed to continue operating to complete the remediation and to continue monitoring activities to verify and monitor the anticipated contaminant removal rates. The treatability study should be considered successfully completed and the remediation should be considered in full operation. 


\section{Background}

\section{Site Description}

The Metallurgical Laboratory (MetLab) waste unit is located in the $A / M$ areas of the SRS. During the 1950's to the early 1980's, solvents were used in MetLab facilities to degrease fuel and target tubes prior to use in other facilities at SRS. The solvents used during this period were primarily trichloroethylene (TCE) and tetrachloroethylene (PCE). Building 717-A is at the center of the soil gas plume and currently houses a machine shop.

\section{Previous Characterization Efforts}

The MetLab characterization was initiated to determine the vertical and lateral extent of contaminants in the vadose zone to aid in determining the source of ground water contamination in the area. MetLab Phase I consisted of installation of seven groundwater monitoring wells and completion of one soil boring near the MetLab Hazardous Waste Management Facility (HWMF). TCE and PCE sediment concentrations in the vadose zone ranged from below detection $(<0.001 \mu \mathrm{g} / \mathrm{g})$ to 0.068 and $0.025 \mu \mathrm{g} / \mathrm{g}$ respectively (Van Pelt and Dunbar, 1995). MetLab Phase II included six CPT characterization and soil gas pushes and groundwater sample collection at three locations. TCE and PCE soil gas concentrations ranged from below detection to 15.1 and 7.2 ppmv respectively (Pemberton, et. al., 1996)

During MetLab Phase III, soil gas samples were collected at twenty-nine locations using a cone penetrometer testing (CPT) truck around the metallurgical manufacturing facility in M-Area. This work expanded lateral vadose zone characterization north and east of the MetLab HWMF. The highest soil gas concentrations were found in an isolated area near building 717-A. Concentrations ranged from 88.4 ppmv TCE and 121.6 PCE ppmv near 717-A to non detect levels at the north end of the characterization area. Other contaminants (e.g. trichloroethane, freon 113, degradation by-products) were also present in the soil gas samples at lower concentrations (Pemberton, et. al., 1997).

The apparent source term is located on the south side of 717-A. The low contaminant concentrations measured in the soil gas $(<15 \mathrm{ppmv})$ at the CPT locations on the north and east side of building 717-A, indicate that the soil gas plume has probably migrated from the apparent source on the south side of Building 717-A. If other source terms were present near the CPT pushes, much higher concentrations would be expected in the soil gas.

\section{Geology}

The Savannah River Site is underlain by a thick wedge (approximately $1000 \mathrm{ft}$ ) of unconsolidated Tertiary and Cretaceous sediments consisting primarily of sands, clayey sands, and sandy clays. Three fine grain layers in the vadose zone at the MetLab are located at approximately $0-15 \mathrm{ft}, 60 \mathrm{ft}$ and $80 \mathrm{ft}$ below ground surface. The 
60 and $80 \mathrm{ft}$ layers are interbedded and range in thickness from approximately 1 to 15 $\mathrm{ft}$. The water table at the site is approximately $140 \mathrm{ft}$ below the ground surface.

\section{Original PSVE Well Installation}

Nineteen vadose zone wells were installed at the MetLab using direct push with a Cone Penetrometer Testing (CPT) truck after the Phase III characterization. The wells were installed by threading a steel push tip onto the PVC screen and pushing the tip with the steel CPT rods in the center of the PVC, effectively pulling the PVC well down with the push tip. The CPT rods are removed and the 6 inch long steel push tip and well remain in the ground.

The wells were installed so the formation was compressed against the outer surface of the casing and screen, leaving no annular space. This seal is verified by sustained gas pressure differences between the surface and subsurface. The wells were installed with continuous screens from 20 to 80 feet below surface. Concrete pads were installed around the wells at the surface.

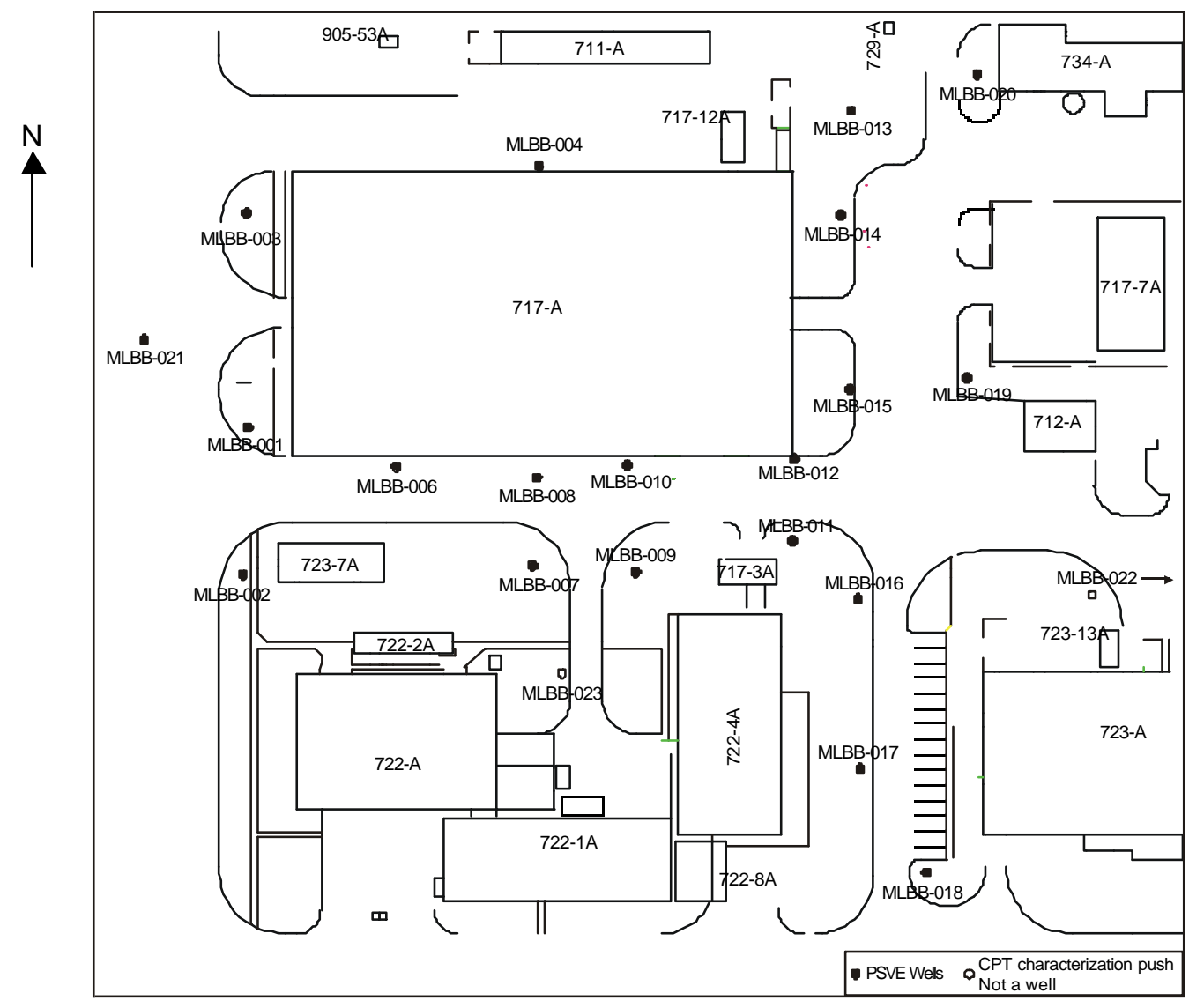

Figure 1 - MetLab Site Map 


\section{Technology Description - Barometric Pumping}

Natural atmospheric pressure fluctuations are transmitted through the unsaturated subsurface, however, these pressure waves are damped and delayed in phase to degrees dependent on the effective vertical permeability of the formation. As a result of the attenuation and delay of the transmitted pressure wave, at a given time the atmospheric pressure at the surface and the soil gas pressure in the subsurface will be different. If these two zones are directly connected (by a vadose zone well), the pressure differential will result in a flow either into or out of the well. If the subsurface contains VOCs in the gas phase, flow out of the well will result in removal of the contaminants from the subsurface without mechanical pumping. This phenomena has been observed for more than a century, (the first reference in the literature is an article in Science, 1897 by Fairbanks) but has only recently been proposed for environmental remediation. The technology is also known as barometric pumping. The duration of flow events (either flow into the well or flow out of the well) can be as long as three days continuously but, as expected by mass balance considerations, the average time of flow in is equal to the average time of flow out. The flow rates for a typical well are generally low (1 to $10 \mathrm{scfm}$ ) but if the concentration of the contaminant in the gas phase is high, mass removal by this process can be significant. Rates as high as 1 to 2 $\mathrm{kg} /$ day/well have been observed near sources in the A/M Area of SRS. Mass removal can be enhanced using low cost or natural techniques. Enhancements to PSVE include the addition of wind powered turbine vacuum pumps, installation of one way mechanical valves to prevent dilution of the contaminated soil gas by clean air from the surface, and solar heat injection to raise vapor pressures and the partitioning of the VOCs from the liquid or aqueous phases to the gas phase.

The BaroBall is a device developed and patented by WSRC specifically for barometric pumping applications. It uses a lightweight ball in a conical seat to permit gas flow in one direction with a minimal pressure requirement (approximately 1 millibar) but effectively prevents gas flow in the reverse direction. Depending on the configuration, the BaroBall can be used to allow contaminated soil gas out of a well and prevent clean air from diluting the soil gas in the subsurface (standard mode of operation), to inject air and/or nutrients into the subsurface to enhance bioremediation, to control or confine the movement of a subsurface gas phase plume in the vadose zone, or to passively transfer solar heated, water-saturated air into the subsurface to enhance volatilization in the subsurface. The BaroBall device is attached directly to the top of the well casing at the surface.

Application of this technology is directed to any site where volatile substances (chlorinated solvents, petroleum products, etc.) have contaminated the vadose zone. Natural pressure fluctuations and their damped and delayed transmission through the subsurface occur in all environments but are particularly well-suited to sites with large vadose zones or substantial low permeability layers that increase the damping and delay of the atmospheric pressure signal. 
Field scale studies have been ongoing at SRS, the Hanford site and the Idaho National Environmental Engineering Lab for approximately six years, and a field scale implementation of the technology for control of subsurface methane migration using a combination of passive injection and extraction was installed at a landfill in Richmond County, Georgia. In addition several other contaminated sites, both public and private, have implemented barometric pumping remediation programs with the BaroBall. The 1996 start of PSVE at the SRS Miscellaneous Chemical Basin was the first implementation to directly target the removal of the vadose zone source term. 


\section{Methods}

\section{Additional Characterization Work in FY00}

Additional characterization was completed in FY00 to evaluate the concentration of the soil gas plume on the south and west sides of the well field.

One PSVE well (MLBB-021) was installed to the west of Building 717-A as a technology demonstration and to characterize and bound the western side of the plume. The well was installed using a Geoprobe with 3 inch casing and the well was completed with sand pack with a bentonite seal. The well provides a significant amount of flow. The well was installed to depth of $52 \mathrm{ft}$ with a screen zone from 30 to $50 \mathrm{ft}$ and a $2 \mathrm{ft}$ sump. This was the first time a well has been installed in this manner at SRS. The success of this new technology deployment provides an additional tool for lower cost shallow and vadose zone well installations without generation of investigative derived waste (IDW). The Geoprobe and operators were provided by Miller Drilling Company as a demonstration of their capabilities.

Two soil gas characterization pushes were completed to depths of approximately $100 \mathrm{ft}$ with the DOE Subsurface Characterization and Penetration System (SCAPS) truck using the standard CPT and the Conesipper ${ }^{\mathrm{TM}}$ soil gas and water sampling tool. One push was done to the north of Building 723-A and the other push was done east of Building 722-A. The soil gas was analyzed using an Innova Model 1312 Multi Gas Analyzer with confirmatory gas chromatography analysis on several samples.

One soil gas push was completed using the new CPT Wire Line Tool near 722-A. This new tool is a recently developed wireline CPT system that allows various tools to be placed at the tip of the rod string depending on the type of information or sample desired while the rod remains in the ground. The wireline piezocone tool has been validated statistically against American Society of Testing and Materials (ASTM) standard cones and the depth capability of the system was found to compare favorably with that of conventional CPT. The Wire Line Piezo Cone was withdrawn from the rods leaving the rods open at the bottom and soil gas was pumped directly through the rods. Flow rates of $1.5 \mathrm{cfm}$ were observed (maximum capacity of the pump) with the Wire Line sampling method that resulted in a radius of capture of approximately $4 \mathrm{ft}$ in 10 minutes. Usual flow rates with the CPT and Consipper are $0.1 \mathrm{cfm}$. This new method for soil gas sampling decreases the time to purge the lines and pull a sample and dramatically increases the radius of capture for soil gas sampling. The CPT Wireline Soil Sampler was developed by Applied Research Associates (ARA, Inc.) with funding from the Department of Energy's National Energy Technology Laboratory (NETL).

\section{Well Vapor Sampling and Analysis Methods}

Concentration measurements were made on the vadose zone wells during barometric pumping outflow events. Well vapor was sampled and analyzed using a Innova Model 
1312 photo-acoustic infrared gas analyzer (new model of the Bruel and Kjaer Model 1302). The instrument was calibrated to measure TCE, PCE, Freon 113 and $\mathrm{CO}_{2}$. The Freon-113 interference problems on the instrument were corrected in January 2000 and a reliable measurement is now possible with the infrared instrument. The correction was done by installing an additional band pass optical filter in the instrument to measure Freon-113 and to compensate for interference of the Freon-113 on the optical filters used to measure TCE and PCE. Samples were also obtained in Tedlar sample bags and analyzed on an HP 5890 series gas chromatograph (GC) to verify the reliability of the infrared instrument. 


\section{Results and Discussion}

\section{FY00 Characterization Results}

Additional characterization was completed in FY00 to evaluate the concentration of the soil gas plume on the south and west sides of the well field. The purpose of the characterization was to estimate the boundary of the plume and determine if additional wells were needed to effectively remediate the area. CPT push MLBB-022 was also used to revisit a higher concentration measurement encountered during the Phase I characterization in 1995. The higher concentration was not encountered. The locations of these pushes are shown in Figure 1. The maximum soil gas concentrations observed from both CPT soil gas pushes were 3.0 ppmv PCE, 3.5 ppmv TCE, and 4.5 ppmv Freon 113. The analysis results are provided in Tables 1 and 2. The CPT friction ratio and soil classification for each push is provided in Figure 2. The friction ratio is a general measure of soil types where higher friction ratios indicate finer grained material. Additional wells were not installed due to the low concentrations. New PSVE wells at these locations would not generate significant mass removal and the existing wells are adequately addressing the soil gas plume on the south side.

One PSVE well (MLBB-021) was installed to the west of Building 717-A as a technology demonstration and to characterize and bound the western side of the plume. The well is screened from 20 to $50 \mathrm{ft}$. The target depth of $80 \mathrm{ft}$ was not reached due to an equipment failure. When the equipment is functioning, it appeared the depth would be achievable. The well provides a significant amount of flow and provides a good boundary measurement for the soil gas plume. Based on the new characterization data and the monitoring results from the existing wells, the current well system adequately bounds the soil gas plume.

Table 1 - MLBB-022 Soil Gas Characterization Results

\begin{tabular}{|l|c|c|c|c|c|c|c|}
\hline $\begin{array}{l}\text { Infrared Analyzer Results } \\
\text { (ppmv) }\end{array}$ & \multicolumn{3}{|l|}{$\begin{array}{l}\text { GC Results } \\
\text { (ppmv) }\end{array}$} \\
\hline $\begin{array}{l}\text { Depth } \\
\text { (ft) }\end{array}$ & $\begin{array}{l}\text { Freon } \\
113\end{array}$ & PCE & TCE & CO2 & $\begin{array}{l}\text { Freon } \\
113\end{array}$ & PCE & TCE \\
\hline 20 & 1.37 & 0.42 & 0.21 & 12300 & & & \\
\hline 29 & 1.59 & 1.25 & 0.69 & 16100 & & & \\
\hline 36 & 2.11 & 1.23 & 0.85 & 15000 & & & \\
\hline 46 & 2.73 & 1.41 & 1.12 & 17300 & & & \\
\hline 70 & 4.04 & 1.27 & 1.82 & 17000 & 4.54 & 0.64 & 1.22 \\
\hline 90 & 0.00 & 0.97 & 0.96 & 8700 & & & \\
\hline 102 & 0.00 & 0.91 & 0.99 & 9010 & & & \\
\hline 107 & 0.85 & 0.00 & 0.05 & 5320 & & & \\
\hline
\end{tabular}


Table 2 - MLBB-023 Soil Gas Characterization Results

\begin{tabular}{|c|c|c|c|c|c|c|c|c|c|c|c|}
\hline \multicolumn{5}{|c|}{$\begin{array}{l}\text { Infrared Analyzer Results } \\
\text { (ppmv) }\end{array}$} & \multicolumn{7}{|c|}{$\begin{array}{l}\text { GC Results } \\
\text { (ppmv) }\end{array}$} \\
\hline $\begin{array}{l}\text { Depth } \\
\mathrm{ft}\end{array}$ & \begin{tabular}{|l} 
Freon \\
113
\end{tabular} & PCE & TCE & $\mathrm{CO} 2$ & \begin{tabular}{|l} 
Freon \\
113
\end{tabular} & PCE & TCE & $\begin{array}{l}11 \\
D C E\end{array}$ & $\mathrm{CCl} 4$ & $\begin{array}{l}\text { CFC } \\
11\end{array}$ & TCA \\
\hline 14 & 0.23 & 0.00 & 0.16 & 6680 & & & & & & & \\
\hline 25 & 0.00 & 0.47 & 0.98 & 6610 & & & & & & & \\
\hline 35 & 0.00 & 0.41 & 0.48 & 3190 & & & & & & & \\
\hline 46 & 0.00 & 0.48 & 0.76 & 5290 & & & & & & & \\
\hline 58 & 0.00 & 0.95 & 1.79 & 6730 & 0.09 & 0.63 & 1.55 & $\mathrm{Nd}$ & nd & nd & nd \\
\hline 68 & 0.00 & 1.39 & 1.96 & 10500 & & & & & & & \\
\hline 78 & 0.00 & 1.38 & 2.05 & 8470 & & & & & & & \\
\hline 88 & 1.56 & 3.00 & 3.45 & 13000 & 2.32 & 1.67 & 2.85 & 0.14 & 0.02 & 0.21 & 0.0 \\
\hline 95 & 0.64 & 2.33 & 2.57 & 11100 & & & & & & & \\
\hline
\end{tabular}

Ratio COR

(\%)

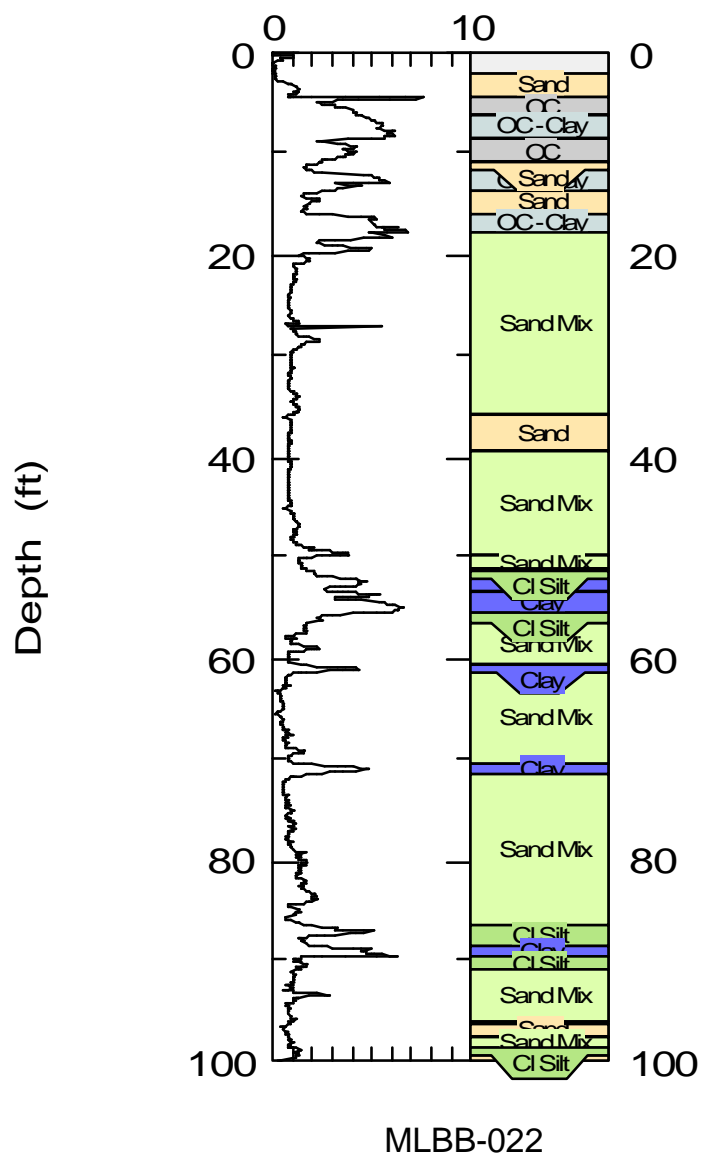

Ratio COR

(\%)

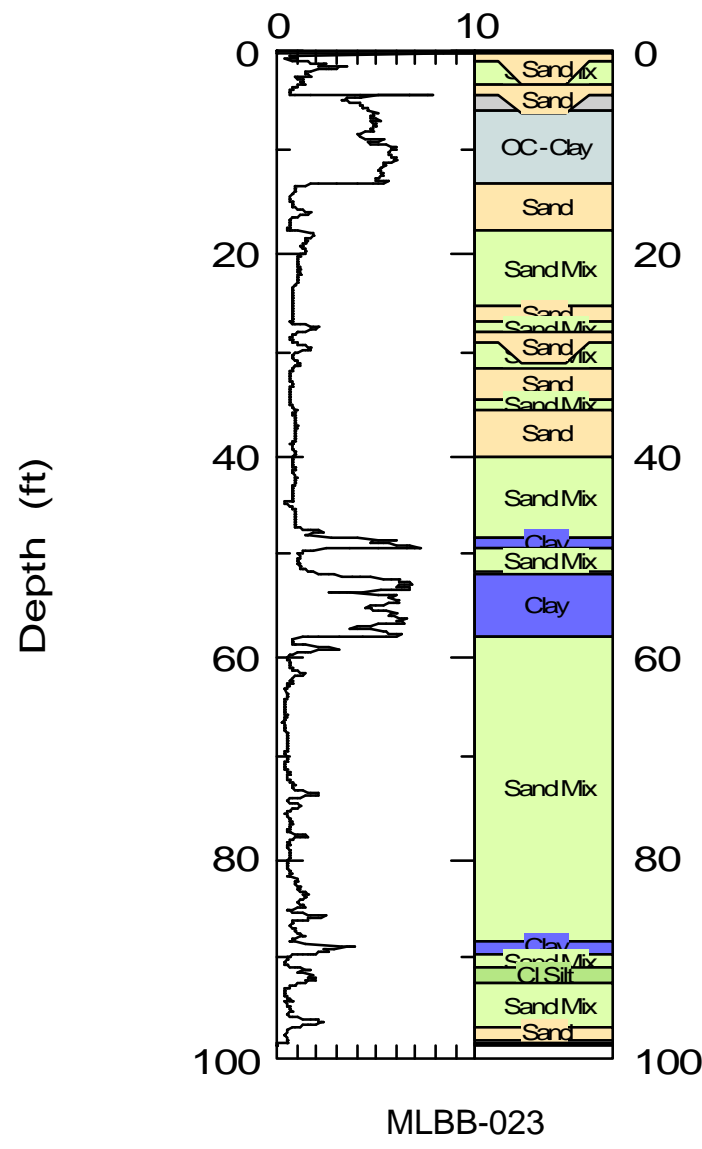

Figure 2 - CPT Soil Classification for MLBB-022 and MLBB-023 


\section{Well Flow Rates and Vapor Concentration}

Well vapor concentration measurements show mass removal and a concentration decrease in the vadose zone at the MetLab. Wellhead measurements were made during outflow events with an infrared photo-acoustic analyzer calibrated for PCE, TCE, Freon-113 and $\mathrm{CO}_{2}$. The contaminant concentrations were normalized with the $\mathrm{CO}_{2}$ concentrations to the average soil gas $\mathrm{CO}_{2}$ levels of each well. This normalization provides a more realistic representation of soil gas concentration in the subsurface by correcting for surface air dilution. The Baroballs leak slightly during inflow periods which dilutes the soil gas and produces low readings during the beginning of outflow events. Monitoring of sealed vadose zone wells have shown $\mathrm{CO}_{2}$ concentrations are fairly constant in the subsurface. However, varying concentrations of $\mathrm{CO}_{2}$ have been observed to correlate to the TCE and PCE concentrations in individual wells at the Miscellaneous Chemical Basin after four years of monitoring. This is attributed to infiltrating surface air diluting the soil gas concentration of both $\mathrm{CO}_{2}$ and the contaminants in a particular well. The normalized concentration values are provided in Appendix A. Both the Innova and the GC values are provided but only the GC values were used for calculations up to January 2000. The Innova data was used for calculations starting in January 2000.

Soil gas concentrations measured over this 2 year time period show an exponentially declining concentration as is expected based on a conceptual model of mass transfer from the liquid or aqueous phase in the fine grain zones to the gas phase in the coarse grain sediments. The early data is limited and most data points used for the exponential fits do not cover the entire 2 year period. The date range and number of data points used for each fit is provided in Table 3 along with the average Freon 113 concentrations. The data is provided in Appendix A.

The concentrations were projected back to the start of the PSVE (May 1998) to estimate size and concentration of the soil gas plume and mass removal. An average concentration was used for the lower concentration wells due to the variability of the analysis instrument at the low concentrations. The parameters for the exponential concentration decline equations are provided in Table 4 and 5 . Selected concentration trends along with the correlation coefficient (quality of fit) from several wells are shown in Figure 3 and 4. 
Table 3 - Trend Data Information and Average Freon-113 Concentrations for MetLab Vadose Zone Plume

\begin{tabular}{|c|c|c|c|}
\hline Well ID & $\begin{array}{c}\text { Number of Data Points } \\
\text { used for Trends or } \\
\text { Average Values }\end{array}$ & Date Range & $\begin{array}{c}\text { Average } \\
\text { Freon } \\
113, \text { ppmv }\end{array}$ \\
\hline MLBB-001 & 10 & $10 / 14 / 97-3 / 27 / 00$ & 0.50 \\
\hline MLBB-002 & 7 & $12 / 29 / 98-3 / 27 / 00$ & 0.79 \\
\hline MLBB-003 & $9^{*}$ & $12 / 29 / 98-3 / 27 / 00$ & 0.24 \\
\hline MLBB-004 & 8 & $12 / 29 / 98-3 / 27 / 00$ & 1.12 \\
\hline MLBB-006 & 7 & $11 / 24 / 98-3 / 27 / 00$ & 0.70 \\
\hline MLBB-007 & 7 & $12 / 29 / 98-3 / 27 / 00$ & 2.04 \\
\hline MLBB-008 & 12 & $5 / 8 / 98-3 / 27 / 00$ & 0.91 \\
\hline MLBB-009 & 9 & $12 / 29 / 98-3 / 27 / 00$ & 2.75 \\
\hline MLBB-010 & 10 & $11 / 24 / 98-3 / 27 / 00$ & 1.08 \\
\hline MLBB-011 & 9 & $12 / 29 / 98-3 / 27 / 00$ & 3.07 \\
\hline MLBB-012 & 9 & $12 / 16 / 98-3 / 27 / 00$ & 0.76 \\
\hline MLBB-013 & $9^{*}$ & $12 / 29 / 98-3 / 27 / 00$ & 0.76 \\
\hline MLBB-014 & $8^{*}$ & $12 / 29 / 98-3 / 27 / 00$ & 0.58 \\
\hline MLBB-015 & 9 & $12 / 16 / 98-3 / 27 / 00$ & 1.45 \\
\hline MLBB-016 & $9^{*}$ & $12 / 29 / 98-3 / 27 / 00$ & 3.71 \\
\hline MLBB-017 & $8^{*}$ & $12 / 29 / 98-3 / 27 / 00$ & 3.79 \\
\hline MLBB-018 & $9^{*}$ & $12 / 29 / 98-3 / 27 / 00$ & 3.70 \\
\hline MLBB-019 & $9^{*}$ & $3 / 25 / 99-3 / 27 / 00$ & 0.89 \\
\hline MLBB-020 & $8^{*}$ & $5 / 24 / 99-3 / 27 / 00$ & 0.65 \\
\hline
\end{tabular}

* Measurement results were averaged for one or both compounds

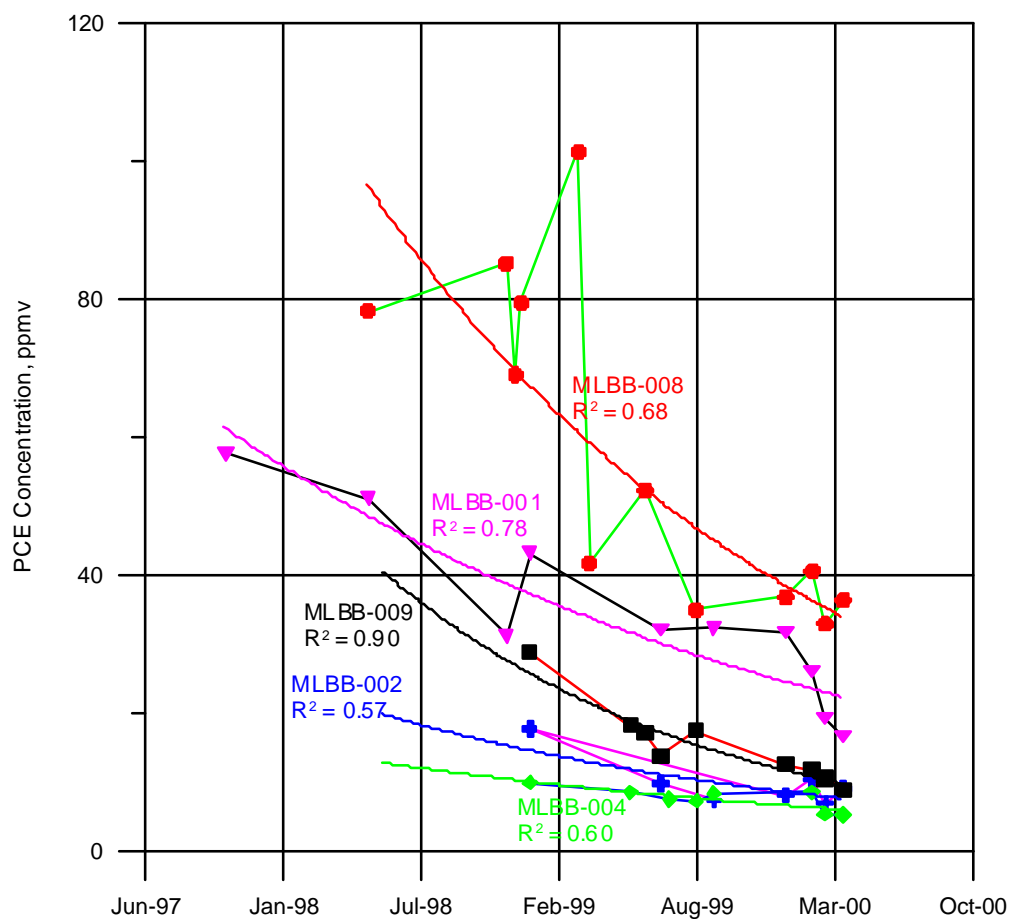

Figure 3 - PCE Well Vapor Concentration Trends for MetLab Vadose Zone Plume 


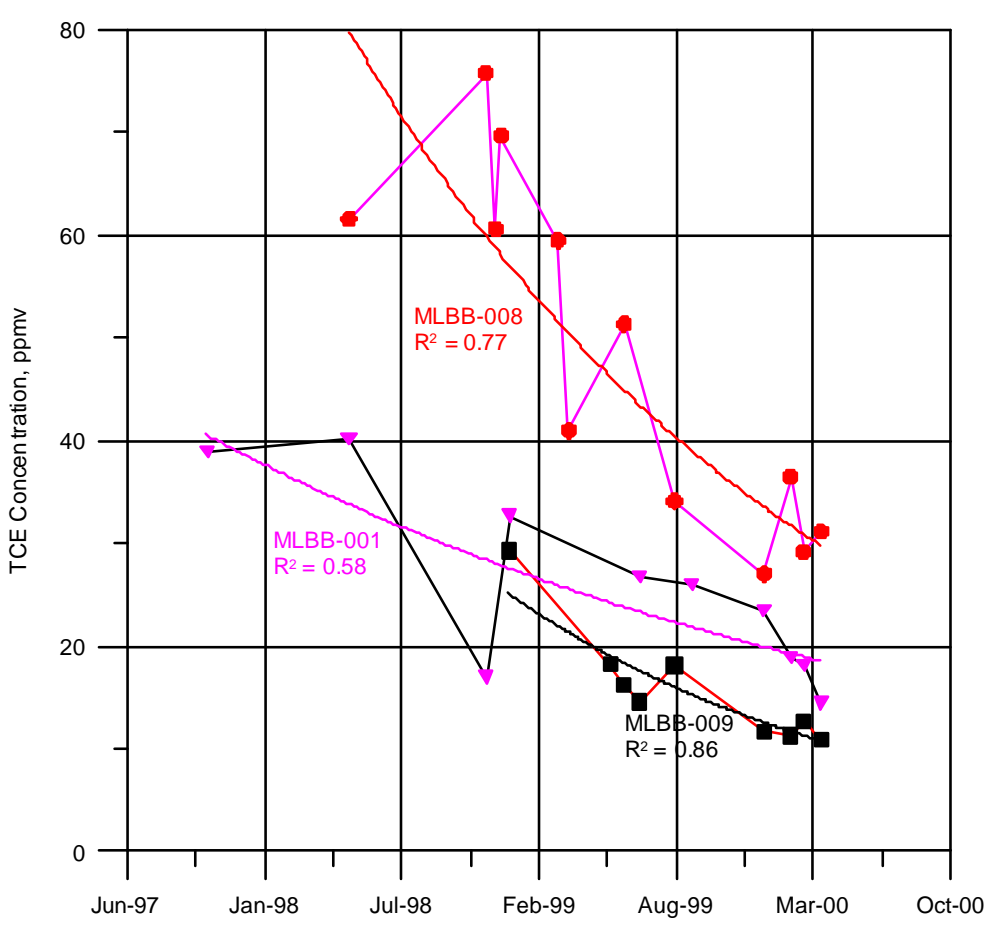

Figure 4 - TCE Well Vapor Concentration Trends for MetLab Vadose Zone Plume

Concentration contour plots of TCE and PCE well concentrations at 6/98, 1/99, 6/99, $1 / 00$ and projected to $6 / 00$ are provided in Figures 5 through 10 . The wells have long screens (60 ft) so these plots show a general representation of the soil gas plume at the unit. Over the 2 years of PSVE with Baroball flow enhancement, the soil gas plume has decreased in concentration and size. The contours were created using the fitted exponential equations. These contour plots show the PSVE is decreasing the size and mass of the plume and is adequately covering the soil gas plume. 


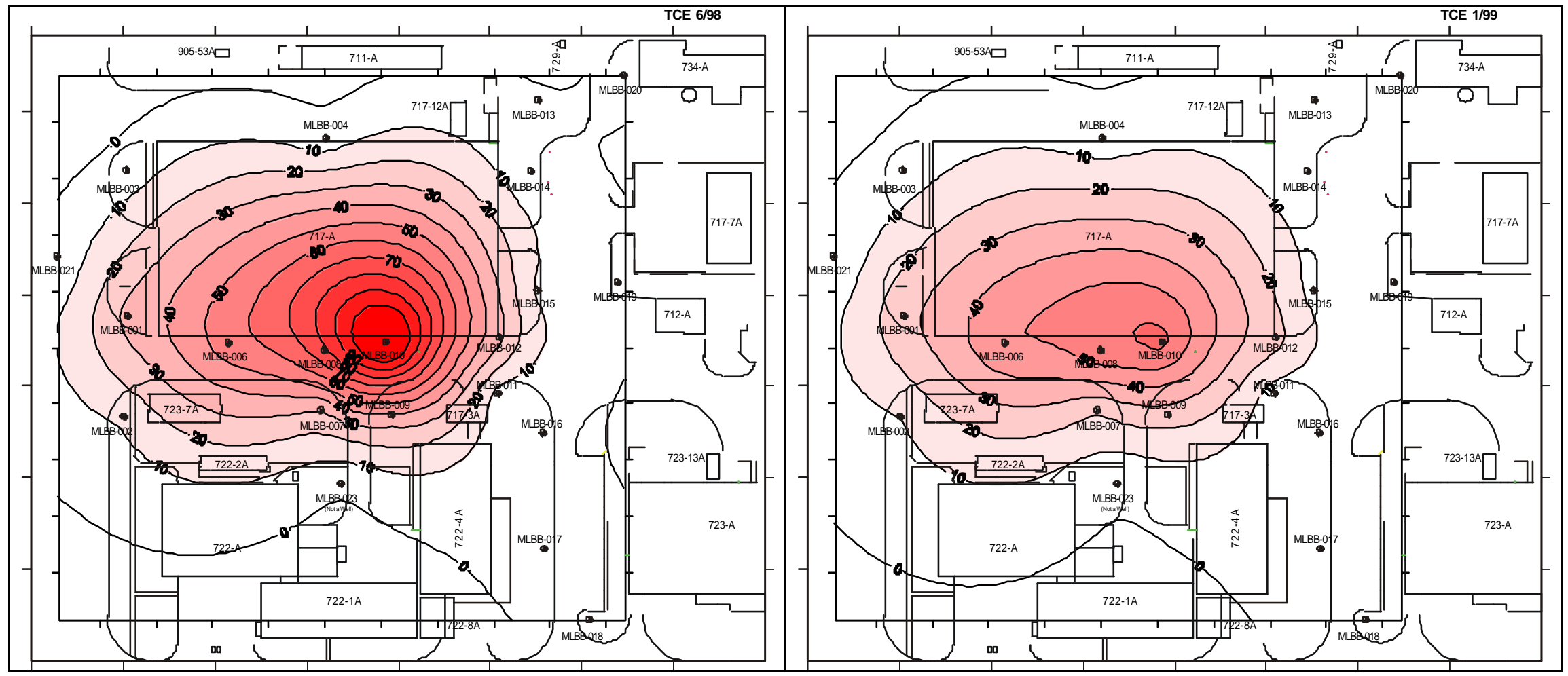

Figure 5 - TCE Soil Gas Plume Contours for MetLab Vadose Zone, ppmv (6/98 and 1/99) 

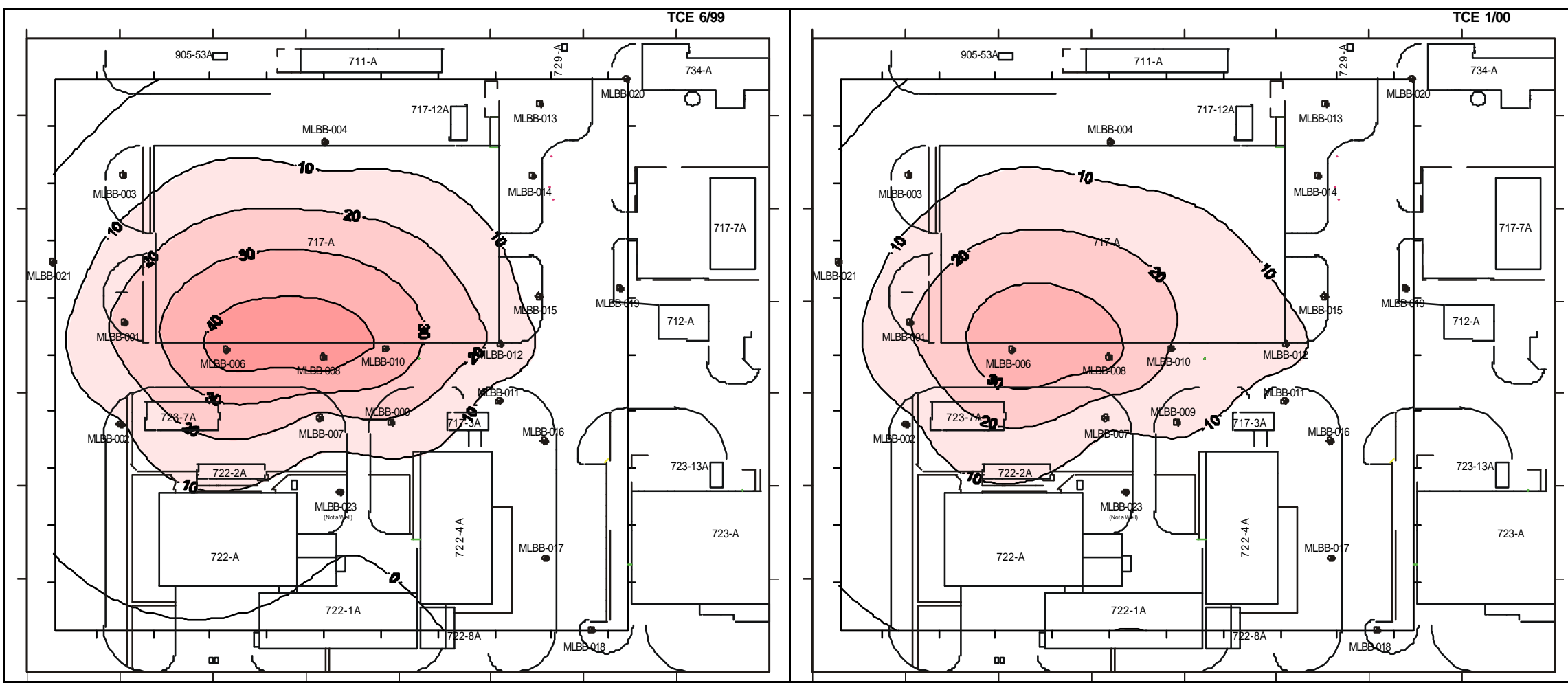

Figure 6 - TCE Soil Gas Plume Contours for MetLab Vadose Zone, ppmv (6/99 and 1/00) 


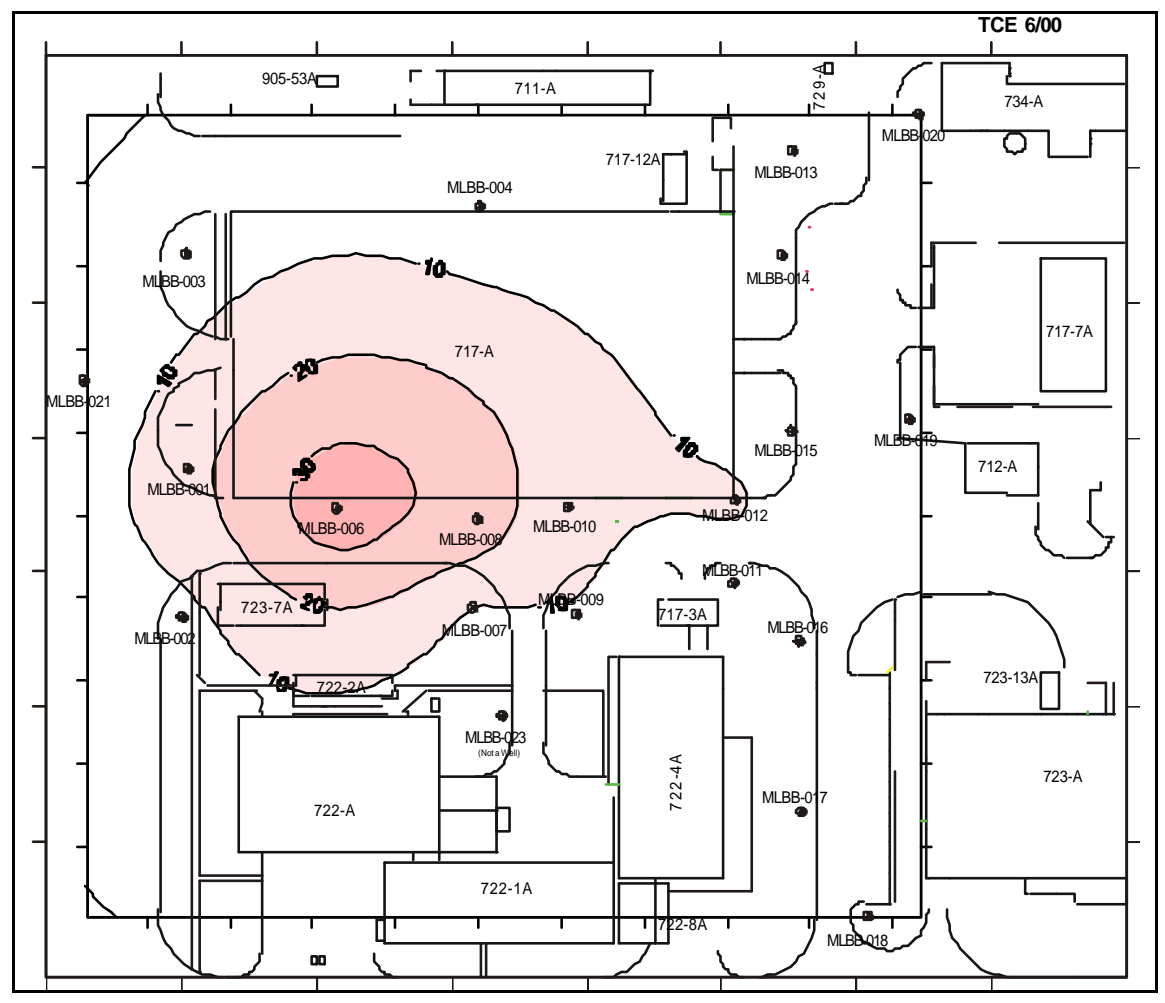

Figure 7 - TCE Soil Gas Plume Contours for MetLab Vadose Zone, ppmv (6/00) 


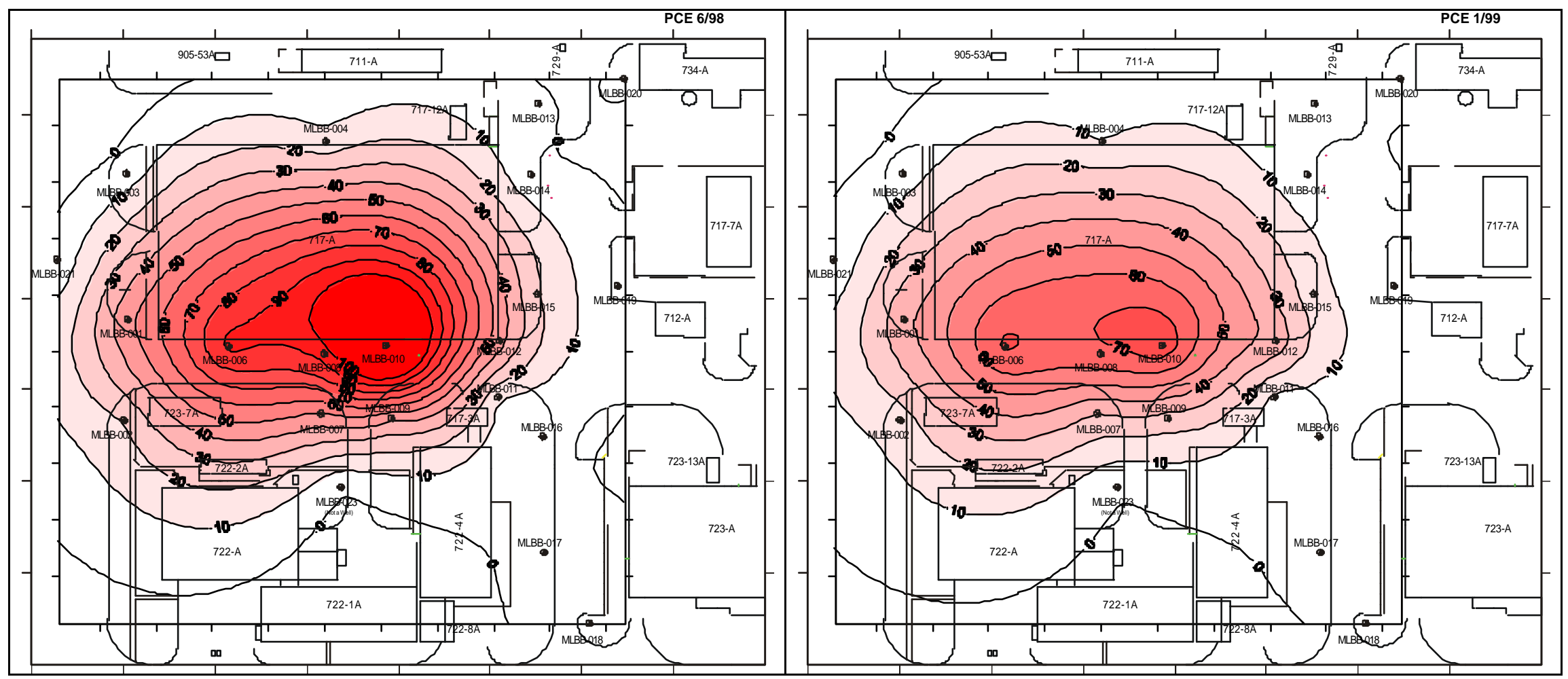

Figure 8 - PCE Soil Gas Plume Contours for MetLab Vadose Zone, ppmv (6/98 and 1/99) 

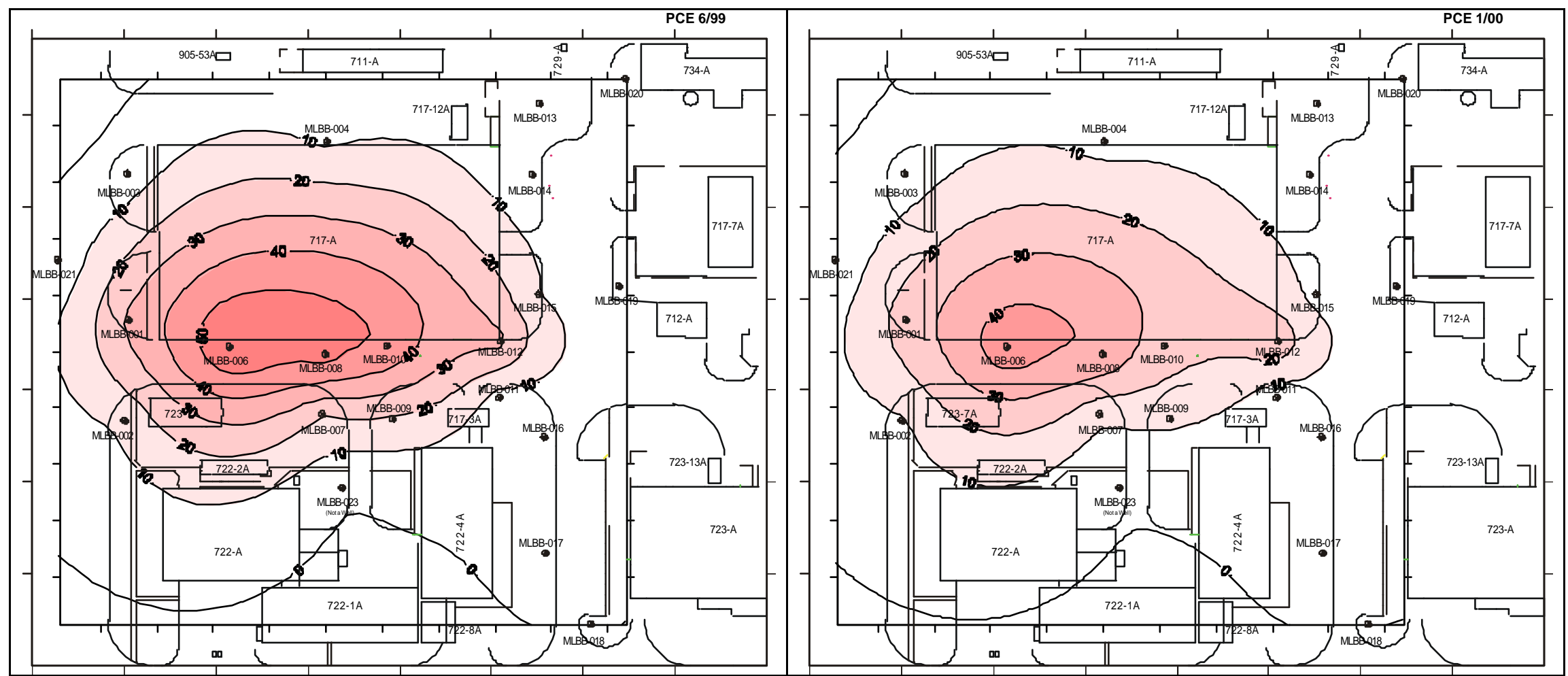

Figure 9 - PCE Soil Gas Plume Contours for MetLab Vadose Zone, ppmv (6/99 and 1/00) 


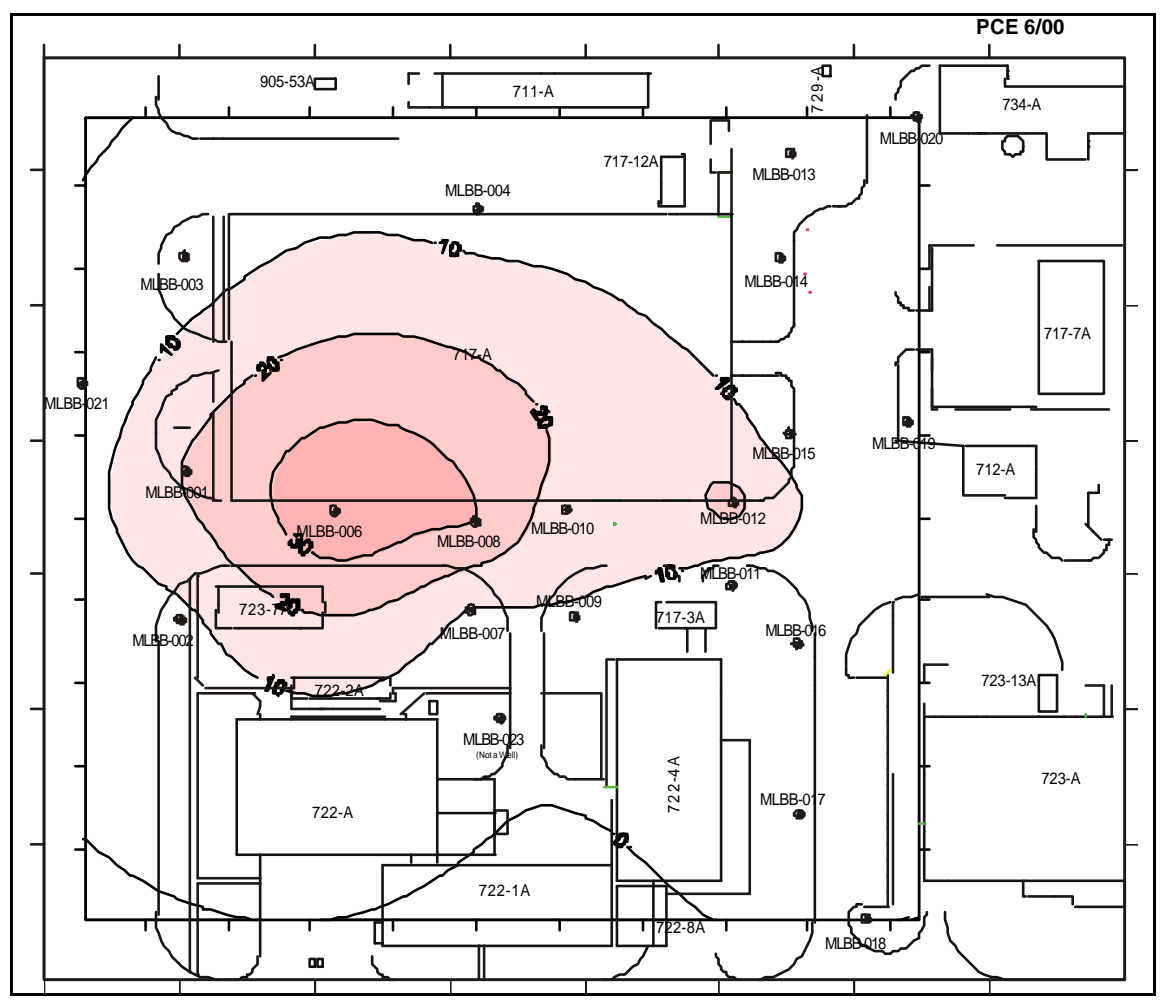

Figure 10 - PCE Soil Gas Plume Contours for MetLab Vadose Zone, ppmv (6/00) 


\section{Flow Control Enhancement of Mass Removal}

Flow control enhancement has been proven to increase mass removal by at least a factor of 2 (May et al., 1994 and Rossabi, 1999). Theoretically, without any engineering controls, the volume of soil gas outflow is approximately equal to the volume inflow in an open vadose zone well. Under these conditions, air entering the vadose zone will dilute the soil gas and force the soil gas plume away from the well. The soil gas removed after an inflow event will thus be a mixture of surface air and soil gas, effectively reducing the mass of contaminants removed.

With flow control which only allows outflow, the soil gas is not diluted and a step process is created which brings contaminants from further distances from the well screen with each successive outflow event. Also, when wells are not flowing out (checked inflow event), contaminants will move into the coarse grained sediments by mass transfer and will be removed during the next outflow event(s). The Baroball check valves have been observed to leak slightly during some inflow events. The leakage is probably caused by some particulate matter (dirt or insects) interfering with the sealing of the ball in the seat. The leakage has been observed to stop after the next outflow event. The leakage rate will be monitored with the flow measurements. The leakage will produce some subsurface dilution dependent on the length of the inflow event.

\section{Mass Removal Estimation}

Based on the concentration curves for 19 wells installed at MetLab, the mass of contaminants removed can be estimated. The assumptions include a uniform average flow rate of $1 \mathrm{cfm}$ out of all of the wells based on measured flow from other PSVE wells, initial concentrations estimated from the concentration trends on 5/1/98 and final concentration projected using the rate constants from approximately 2 years of monitoring. Physically observed vapor flow and concentration measurements indicate mass removal from the vadose zone at the MetLab.

Well flow rates have not been measured at the MetLab so PSVE flow rates from nearby wells are used for estimating the mass removal. Continuous flow measurements will be made in FY00. The average flow measured from 2 inch diameter PSVE wells at the Miscellaneous Chemical Basin and near the M-Area Basin is approximately $2 \mathrm{cfm}$ during outflow events. Since soil gas is removed $50 \%$ of the time with barometric pumping, the continuous average flow out of the wells is $1 \mathrm{cfm}$. The area under the removal curves is calculated and multiplied by the flow rate to obtain the mass of contaminant removed. The total mass removed at the MetLab for a given time period is the sum of the mass removed from the individual wells. The calculated mass removal is presented in Tables 4 and 5 and a graph showing the mass removal trend is provided in Figure 11.

After 2 years of PSVE approximately $100 \mathrm{lbs}$ TCE and $170 \mathrm{lbs}$ PCE have been removed by the natural barometric pumping of wells fitted with BaroBall valves. The 
mass removal estimates are approximate since the flow rates are estimated, the concentration data is based on exponential fits of the data set, and the concentration data is normalized to the average $\mathrm{CO}_{2}$ concentrations.

At the current fitted removal rates all the wells will be below 5 ppmv by the end of 2001 except for MLBB-001, 006, 008, and 012. Based on the current fitted data and projecting the concentration trends, all the wells will be below 5 ppmv by $1 / 2005$. At that time, less than $10 \mathrm{lbs}$ of solvents will be removed each year. The initial mass estimate of the contaminant source (removal to 1/2005) is $170 \mathrm{lbs}$ TCE and $250 \mathrm{lbs}$ PCE. These masses correspond to approximately 14 gallons $(53 \mathrm{I}$ ) of TCE and 18 gallons (70 I) of PCE present in the subsurface at the site.

Table 4 - Fitted PCE Concentration Data and Estimated Mass Removed by Well for the MetLab Vadose Zone Plume

\begin{tabular}{|c|c|c|c|c|c|c|c|c|}
\hline \multirow[b]{3}{*}{ Well ID } & \multirow{3}{*}{$\begin{array}{c}\text { Decay } \\
\text { Constant } \\
\text { A }\end{array}$} & \multicolumn{4}{|c|}{$\begin{array}{c}\text { Well Vapor PCE } \\
\text { Concentration, ppmv }\end{array}$} & \multicolumn{3}{|c|}{$\begin{array}{c}\text { Cumulative PCE Mass } \\
\text { Removed, lbs }\end{array}$} \\
\hline & & 0 -Year & 1-Year & & 2-Year & 1-Year & & 2-Year \\
\hline & & May-98 & Jun-99 & Jan-00 & Jun-00 & Jun-99 & Jan-00 & Jun-00 \\
\hline MLBB-001 & $-1.12 \mathrm{E}-03$ & 49.16 & 31.52 & 24.78 & 20.90 & 10.32 & 13.90 & 15.98 \\
\hline MLBB-002 & $-1.42 E-03$ & 20.74 & 11.81 & 8.71 & 7.01 & 4.13 & 5.42 & 6.13 \\
\hline MLBB-003 & Average Used & 4.27 & 4.27 & 4.27 & 4.27 & 1.11 & 1.66 & 2.06 \\
\hline MLBB-004 & $-1.12 \mathrm{E}-03$ & 13.33 & 8.56 & 6.73 & 5.68 & 2.80 & 3.77 & 4.34 \\
\hline MLBB-006 & $-1.19 \mathrm{E}-03$ & 96.33 & 60.21 & 46.71 & 39.00 & 19.99 & 26.77 & 30.67 \\
\hline MLBB-007 & $-2.39 \mathrm{E}-03$ & 51.71 & 20.04 & 12.01 & 8.35 & 8.72 & 10.69 & 11.59 \\
\hline MLBB-008 & $-1.51 \mathrm{E}-03$ & 97.81 & 53.73 & 38.87 & 30.89 & 19.15 & 24.98 & 28.13 \\
\hline MLBB-009 & $-2.12 \mathrm{E}-03$ & 43.26 & 18.69 & 11.87 & 8.60 & 7.63 & 9.52 & 10.44 \\
\hline MLBB-010 & $-3.18 \mathrm{E}-03$ & 171.40 & 48.62 & 24.61 & 15.17 & 25.53 & 29.90 & 31.62 \\
\hline MLBB-011 & $-1.60 \mathrm{E}-03$ & 10.55 & 5.59 & 3.97 & 3.11 & 2.03 & 2.63 & 2.95 \\
\hline MLBB-012 & $-8.79 E-04$ & 45.86 & 32.38 & 26.82 & 23.47 & 10.07 & 13.85 & 16.15 \\
\hline MLBB-013 & Average Used & 0.70 & 0.70 & 0.70 & 0.70 & 0.18 & 0.27 & 0.34 \\
\hline MLBB-014 & $-1.32 E-04$ & 1.81 & 1.72 & 1.67 & 1.64 & 0.46 & 0.68 & 0.83 \\
\hline MLBB-015 & -1.99E-03 & 22.12 & 10.08 & 6.59 & 4.87 & 3.99 & 5.03 & 5.54 \\
\hline MLBB-016 & $-2.97 \mathrm{E}-04$ & 2.09 & 1.86 & 1.75 & 1.67 & 0.51 & 0.75 & 0.90 \\
\hline MLBB-017 & Average Used & 2.47 & 2.47 & 2.47 & 2.47 & 0.64 & 0.96 & 1.19 \\
\hline MLBB-018 & Average Used & 6.24 & 6.24 & 6.24 & 6.24 & 0.58 & 0.61 & 0.61 \\
\hline MLBB-019 & Average Used & 3.24 & 3.24 & 3.24 & 3.24 & 0.84 & 1.26 & 1.56 \\
\hline MLBB-020 & Average Used & 0.80 & 0.80 & 0.80 & 0.80 & 0.21 & 0.31 & 0.39 \\
\hline & & & & & $\begin{array}{l}\text { otal PCE } \\
\text { loved, lbs }\end{array}$ & 118.90 & 152.97 & 171.42 \\
\hline
\end{tabular}

Concentration $(p p m v)=A e^{(B t)}$ where $A$ is $0-$ Year concentration and t is time in days 


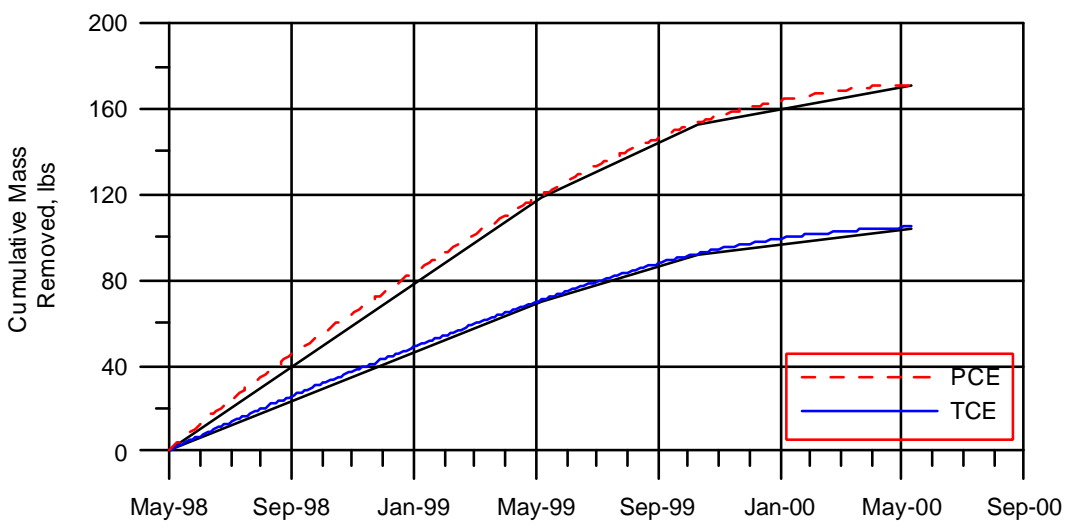

Figure 11 - Cumulative Mass Removed for MetLab Vadose Zone Plume

Table 5 - Fitted TCE Concentration Data and Estimated Mass Removed by Well for the MetLab Vadose Zone Plume

\begin{tabular}{|c|c|c|c|c|c|c|c|c|}
\hline \multirow[b]{3}{*}{ Well ID } & \multirow{3}{*}{$\begin{array}{c}\text { Decay } \\
\text { Constant } \\
\text { A }\end{array}$} & \multicolumn{4}{|c|}{$\begin{array}{c}\text { Well Vapor TCE } \\
\text { Concentration, ppmv }\end{array}$} & \multicolumn{3}{|c|}{$\begin{array}{l}\text { Cumulative TCE Mass } \\
\text { Removed, lbs }\end{array}$} \\
\hline & & 0 -Year & 1-Year & & 2-Year & 1-Year & & 2-Year \\
\hline & & $5 / 1 / 98$ & $6 / 1 / 99$ & $1 / 1 / 00$ & $6 / 1 / 00$ & $6 / 1 / 99$ & $1 / 1 / 00$ & $6 / 1 / 00$ \\
\hline MLBB-001 & $-8.78 \mathrm{E}-04$ & 33.93 & 23.96 & 19.86 & 17.37 & 5.90 & 8.12 & 9.47 \\
\hline MLBB-002 & $-7.75 E-04$ & 11.71 & 8.62 & 7.30 & 6.49 & 2.08 & 2.89 & 3.39 \\
\hline MLBB-003 & Average Used & 3.99 & 3.99 & 3.99 & 3.99 & 0.82 & 1.23 & 1.53 \\
\hline MLBB-004 & Average Used & 3.41 & 3.41 & 3.41 & 3.41 & 0.70 & 1.05 & 1.30 \\
\hline MLBB-006 & $-5.73 E-04$ & 57.35 & 45.71 & 40.43 & 37.06 & 10.57 & 14.96 & 17.78 \\
\hline MLBB-007 & $-1.57 \mathrm{E}-03$ & 30.19 & 16.20 & 11.58 & 9.12 & 4.64 & 6.02 & 6.76 \\
\hline MLBB-008 & -1.44E-03 & 80.83 & 45.73 & 33.61 & 27.01 & 12.71 & 16.68 & 18.85 \\
\hline MLBB-009 & -1.87E-03 & 39.27 & 18.70 & 12.52 & 9.42 & 5.73 & 7.27 & 8.05 \\
\hline MLBB-010 & $-3.21 E-03$ & 139.38 & 39.06 & 19.64 & 12.06 & 16.38 & 19.15 & 20.24 \\
\hline MLBB-011 & $-3.98 E-04$ & 5.30 & 4.53 & 4.16 & 3.92 & 1.01 & 1.45 & 1.75 \\
\hline MLBB-012 & $-1.42 \mathrm{E}-03$ & 33.96 & 19.31 & 14.24 & 11.47 & 5.35 & 7.03 & 7.95 \\
\hline MLBB-013 & Average Used & 0.54 & 0.54 & 0.54 & 0.54 & 0.11 & 0.17 & 0.21 \\
\hline MLBB-014 & Average Used & 2.15 & 2.15 & 2.15 & 2.15 & 0.44 & 0.66 & 0.82 \\
\hline MLBB-015 & $-9.29 E-04$ & 8.10 & 5.60 & 4.59 & 3.99 & 1.40 & 1.91 & 2.22 \\
\hline MLBB-016 & Average Used & 2.42 & 2.42 & 2.42 & 2.42 & 0.50 & 0.75 & 0.93 \\
\hline MLBB-017 & Average Used & 2.93 & 2.93 & 2.93 & 2.93 & 0.60 & 0.91 & 1.12 \\
\hline MLBB-018 & Average Used & 2.19 & 2.19 & 2.19 & 2.19 & 0.45 & 0.68 & 0.84 \\
\hline MLBB-019 & Average Used & 2.43 & 2.43 & 2.43 & 2.43 & 0.50 & 0.75 & 0.93 \\
\hline MLBB-020 & Average Used & 1.09 & 1.09 & 1.09 & 1.09 & 0.22 & 0.34 & 0.42 \\
\hline & & & & & $\begin{array}{l}\text { Total TCE } \\
\text { loved, lbs }\end{array}$ & 70.12 & 92.02 & 104.56 \\
\hline
\end{tabular}

Concentration $(\mathrm{ppmv})=\mathrm{Ae}^{(\mathrm{Bt})}$ where $\mathrm{A}$ is 0 -Year concentration and $\mathrm{t}$ is time in days 


\section{Conclusions}

The results to date on the treatability study of the PSVE system at the MetLab of the Savannah River Site indicate the technology is performing well. Well concentrations are decreasing and contour maps of the vadose zone soil gas plume show a decrease in the extent of the plume. In the 2 years of operation approximately 270 pounds of chlorinated organic contaminants have been removed by natural barometric pumping of wells fitted with BaroBall valves (low pressure check valves). The mass removal estimates are approximate since the flow rates are estimated, the concentration data is based on exponential fits of the data set, and the concentration data is normalized to the average $\mathrm{CO}_{2}$ concentrations.

Additional characterization was completed in FY00 to evaluate the concentration of the soil gas plume on the south and west sides of the well field. One well was installed and two soil gas pushes were completed. The maximum soil gas concentrations observed from both CPT soil gas pushes were 3.0 ppmv PCE, 3.5 ppmv TCE, and 4.5 ppmv Freon 113. Additional wells were not installed due to the low concentrations. Based on the new characterization data and the monitoring results from the existing wells, the current well system adequately bounds the soil gas plume.

At the current fitted removal rates all the wells will be below 5 ppmv by the end of 2001 except for MLBB-001, 006, 008, and 012. Projecting the concentration trends, all the wells will be below 5 ppmv by $1 / 05$. The initial mass estimate of the contaminant source (removal to 1/05) is $170 \mathrm{lbs}$ TCE and $250 \mathrm{lbs}$ PCE. These masses correspond to approximately 14 gallons (53 I) of TCE and 18 gallons (70 I) of PCE present in the subsurface at the site.

Mass removal during this time frame is primarily attributed to residual contamination in the coarse grained material and contaminant mass transfer from the finer grained zones to coarse zones where the majority of the PSVE flow is achieved. Removal from the fine grained sediments will be limited by the mass transfer from these zones to the coarse grained zones.

The PSVE system has required minimal operating and maintenance costs and can be expected to operate continuously for at least 10 years with no intervention. All of the vadose zone extraction wells installed can also be used with an active vapor extraction system. 


\section{Recommendations}

The PSVE system is performing well in a cost-effective manner. The following recommendations are intended to refine the concentration data and estimates of contaminant removal.

- Continue monthly well vapor sampling and analysis to refine the exponential concentration trends and verify the anticipated contaminant removal.

- Monitor PSVE well flow rates.

- Allow the system to continue operating to complete the remediation. The treatability study should be considered completed successfully and the remediation should be considered in full operation.

\section{References}

May, C.P., B.D. Riha, J. Rossabi, B.E. Pemberton, B.B. Looney. 1994. The Influence of Atmospheric Pressure Fluctuations on Soil Gas Sampling. Eos Transactions, American Geophysical Union 1994 Fall Meeting.

Pemberton, B.E., J. Rossabi, B.D. Riha. 1996. Metlab Phase II Sample Analysis Report. SRT-ESS-96-280. Westinghouse Savannah River Company, Aiken, SC.

Pemberton, B.E., J. Rossabi, B.D. Riha. 1997. Metlab Phase III Characterization Report. WSRC-RP-97-4. Westinghouse Savannah River Company, Aiken, SC.

Riha, B.D.. J. Rossabi, and W.K. Hyde. 1999. "Metallurgical Laboratory (MetLab) Treatability Study: An Analysis of Passive Soil Vapor Extraction Wells (PSVE), FY2000 Update". WSRC-TR-99-00373. Westinghouse Savannah River Company, Aiken, SC.

Riha, B.D.. J. Rossabi, and W.K. Hyde. 1999. Miscellaneous Chemical Basin Treatability Study: An Analysis of Passive Soil Vapor Extraction Wells (PSVE), FY1998 Update. WSRC-TR-99-00058. Westinghouse Savannah River Company, Aiken, SC.

Rossabi, J. 1999. The Influence of Atmospheric Pressure Variations on Subsurface Soilgas and the Implications for Environmental Characterization and Remediation. Dissertation. Clemson University, Clemson SC.

Van Pelt, R.S. and T. Dunbar. 1995. A/M Area Metallurgical Laboratory: Summary of Phase I Characterization - Well Installation, Cone Penetrometer Testing, and Soil Core for Headspace Analysis. WSRC-RP-95-1553. Westinghouse Savannah River Company, Aiken, SC. 


\section{APPENDIX A - Well Vapor Concentrations}


WSRC-TR-2000-00182

\begin{tabular}{|c|c|c|c|c|c|c|c|c|c|c|c|c|c|c|c|c|c|c|c|c|c|}
\hline & \multicolumn{4}{|c|}{ MLBB-001 } & \multicolumn{3}{|l|}{ GC } & \multicolumn{4}{|c|}{ MLBB-002 } & \multicolumn{3}{|l|}{$G C$} & \multicolumn{4}{|c|}{\begin{tabular}{|l|} 
MLBB-003 \\
\end{tabular}} & \multicolumn{3}{|l|}{ GC } \\
\hline Date & PCE & TCE & $\mathrm{CO} 2$ & \begin{tabular}{|l|} 
FR113 \\
\end{tabular} & PCE & TCE & FR113 & $\overline{\mathrm{PCE}}$ & TCE & $\mathrm{CO} 2$ & FR113 & PCE & TCE & \begin{tabular}{|l|} 
FR113 \\
\end{tabular} & PCE & TCE & $\mathrm{CO} 2$ & \begin{tabular}{|l|} 
FR113 \\
\end{tabular} & PCE & TCE & FR113 \\
\hline \begin{tabular}{|l|l|l|l|}
$10 / 147$ \\
\end{tabular} & 66.08 & 35.29 & 7300 & & 57.69 & 38.94 & 0.39 & 34.10 & 19.78 & 8130 & & & & & 4.58 & 3.01 & 3750 & & & & \\
\hline 5/8/98 & 50.52 & 32.34 & 5590 & & 51.12 & \begin{tabular}{|l|}
40.19 \\
\end{tabular} & 0.23 & 38.06 & 26.45 & 7850 & & & & & 6.39 & \begin{tabular}{|l|l|}
4.13 \\
\end{tabular} & 7850 & & & & \\
\hline 6/30/98 & \begin{tabular}{|l|l|}
320.64 \\
\end{tabular} & 11.86 & 3790 & & & & & 9.37 & 4.51 & 2600 & & & & & 3.33 & \begin{tabular}{|l|}
2.51 \\
\end{tabular} & 5980 & & & & \\
\hline 8/10/98 & \begin{tabular}{|l|l|}
3 & 25.64 \\
\end{tabular} & 13.78 & 3900 & & & & & 11.17 & 6.02 & 3310 & & & & & 3.38 & 2.60 & 6280 & & & & \\
\hline 9/8/98 & \begin{tabular}{|l|l|}
48.63 \\
\end{tabular} & 26.93 & 6120 & & & & & 25.25 & 14.15 & 4410 & & & & & 3.49 & \begin{tabular}{|l|}
2.37 \\
\end{tabular} & 12600 & & & & \\
\hline $11 / 24 / 98$ & \begin{tabular}{|l|l|}
34.43 \\
\end{tabular} & 17.38 & 3880 & & 31.20 & \begin{tabular}{|l|}
16.97 \\
\end{tabular} & 0.16 & 19.32 & 11.23 & 4970 & & & & & 2.97 & 0.42 & 11800 & & & & \\
\hline 12/8/98 & \begin{tabular}{|l|l|}
30.22 \\
\end{tabular} & 5.79 & 4390 & & & & & & & & & & & & 2.80 & 0.60 & 9010 & & & & \\
\hline 12/16/98 & \begin{tabular}{|l|l|}
18.92 \\
\end{tabular} & 9.51 & 3120 & & 7.77 & 6.10 & nd & 10.05 & 3.18 & 4070 & & & & & 3.67 & \begin{tabular}{|l|}
0.13 \\
\end{tabular} & 9490 & & & & \\
\hline 12/29/98 & 53.60 & 26.50 & 7880 & & 43.22 & 32.65 & 0.25 & 22.34 & 9.69 & 9830 & & 17.77 & 11.76 & 0.78 & 3.35 & \begin{tabular}{|l|}
0.17 \\
\end{tabular} & 13500 & & 2.11 & \begin{tabular}{|l|}
2.07 \\
\end{tabular} & 0.04 \\
\hline $2 / 2 / 99$ & 58.17 & 28.92 & 7330 & & & & & 20.93 & 9.11 & 9230 & & & & & 3.93 & 0.45 & \begin{tabular}{|l|}
11200 \\
\end{tabular} & & & & \\
\hline 3/9/99 & & & & & & & & & & & & & & & & & & & & & \\
\hline $3 / 25 / 99$ & & & & & & & & & & & & & & & & & & & & & \\
\hline $5 / 24 / 99$ & & & & & & & & & & & & & & & 2.88 & \begin{tabular}{|l|}
1.58 \\
\end{tabular} & 10500 & & 2.87 & \begin{tabular}{|l|}
2.34 \\
\end{tabular} & 0.11 \\
\hline 6/14/99 & 4.07 & 5.37 & 1330 & & 5.95 & 5.11 & nd & 0.14 & 3.86 & 1360 & & 9.44 & 7.50 & & & & & & & & \\
\hline 6/15/99 & & & & & & & & & & & & & & & & & & & & & \\
\hline 6/16/99 & & & & & & & & & & & & & & & & & & & & & \\
\hline $6 / 17 / 99$ & & & & & & & & & & & & & & & 0.30 & 1.10 & 6670 & & 0.67 & \begin{tabular}{|l|}
0.97 \\
\end{tabular} & nd \\
\hline 7/7/99 & 40.14 & 30.04 & 8550 & & 32.15 & \begin{tabular}{|l|}
26.75 \\
\end{tabular} & 0.96 & 14.02 & 9.53 & 10100 & & 9.93 & 7.85 & 1.24 & & & & & & & \\
\hline 7/19/99 & & & & & & & & & & & & & & & 6.98 & 5.63 & 11100 & & 6.76 & \begin{tabular}{|l|}
5.07 \\
\end{tabular} & 0.29 \\
\hline $8 / 26 / 99$ & & & & & & & & & & & & & & & & & & & & & \\
\hline $8 / 27 / 99$ & & & & & & & & & & & & & & & 5.16 & \begin{tabular}{|l|}
4.98 \\
\end{tabular} & 10800 & & 5.42 & 4.60 & 0.06 \\
\hline 9/21/99 & 41.85 & 29.94 & 7990 & & 32.41 & \begin{tabular}{|l|}
25.94 \\
\end{tabular} & 0.48 & 12.18 & 7.78 & 7230 & & 7.47 & 6.81 & 0.95 & & & & & & & \\
\hline $11 / 2 / 99$ & 30.26 & 24.71 & 10100 & & & & & 10.61 & 7.92 & 9320 & & & & & 4.99 & \begin{tabular}{|l|}
4.63 \\
\end{tabular} & 10900 & & & & \\
\hline 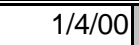 & 31.83 & 23.51 & 8270 & 0.00 & & & & 8.15 & 3.99 & 5390 & 0.00 & & & & 5.93 & \begin{tabular}{|l|}
2.62 \\
\end{tabular} & 10400 & \begin{tabular}{|c|}
0.01 \\
\end{tabular} & & & \\
\hline $2 / 11 / 00$ & 26.16 & \begin{tabular}{|l|}
18.83 \\
\end{tabular} & 9940 & 0.40 & & & & \begin{tabular}{|c|}
10.47 \\
\end{tabular} & 7.02 & 7900 & 0.21 & & & & 4.19 & \begin{tabular}{|l|l|}
5.17 \\
\end{tabular} & 10500 & 0.00 & & & \\
\hline $3 / 1 / 00$ & \begin{tabular}{|l|l|} 
& 19.34 \\
\end{tabular} & \begin{tabular}{|l|}
18.17 \\
\end{tabular} & 10300 & 0.61 & & & & 7.07 & 9.72 & 7640 & 0.71 & & & & 5.55 & \begin{tabular}{|l|}
6.55 \\
\end{tabular} & 10700 & 0.45 & & & \\
\hline $3 / 27 / 00$ & 16.68 & 14.49 & 10600 & 1.05 & & & & 9.20 & 9.22 & 8990 & 0.84 & & & & 4.89 & 6.50 & 10800 & 0.74 & & & \\
\hline
\end{tabular}

All concentrations in ppmv and normalized by $\mathrm{CO}_{2}$ levels.

Shaded values are from the B\&K. Non-shaded values are from gas chromatography analysis

nd $=$ not detected

italicized values were not used - low $\mathrm{CO}_{2}$ indicates non-representative sample 
WSRC-TR-2000-00182

\begin{tabular}{|c|c|c|c|c|c|c|c|c|c|c|c|c|c|c|c|c|c|c|c|c|c|}
\hline \multicolumn{5}{|c|}{ MLBB-004 } & \multicolumn{3}{|l|}{ GC } & \multicolumn{4}{|c|}{ MLBB-006 } & \multicolumn{3}{|l|}{ GC } & \multicolumn{4}{|c|}{ MLBB-007 } & \multicolumn{3}{|l|}{ GC } \\
\hline Date & PCE & TCE & $\mathrm{CO} 2$ & FR113 & PCE & TCE & FR113 & PCE & TCE & $\mathrm{CO} 2$ & FR113 & PCE & TCE & FR113 & PCE & TCE & $\mathrm{CO} 2$ & FR113 & PCE & TCE & FR113 \\
\hline $10 / 14 / 97$ & 18.43 & 10.64 & 8140 & & & & & 85.96 & 57.42 & 3490 & & & & & 29.03 & 22.49 & 2220 & & & & \\
\hline $5 / 8 / 98$ & 17.45 & 8.88 & 8390 & & & & & 108.99 & 67.83 & 4140 & & & & & 66.38 & 45.12 & 5080 & & & & \\
\hline $6 / 30 / 98$ & 11.36 & 5.81 & 11300 & & & & & 60.67 & 36.07 & 3560 & & & & & 20.34 & 15.81 & 1670 & & & & \\
\hline $8 / 10 / 98$ & 10.17 & 4.91 & 10700 & & & & & 61.76 & 36.47 & 3070 & & & & & 21.85 & 10.68 & 1450 & & & & \\
\hline 9/8/98 & 10.91 & 4.88 & 12100 & & & & & 76.45 & 47.18 & 4960 & & & & & 32.58 & 19.51 & 3020 & & & & \\
\hline $11 / 24 / 98$ & 15.61 & 3.01 & 11300 & & & & & 82.01 & 44.02 & 3980 & & 63.14 & 42.51 & 0.33 & 20.49 & 13.89 & 2800 & & & & \\
\hline 12/8/98 & 12.40 & 2.94 & 11900 & & & & & 40.44 & 22.58 & 2620 & & 88.76 & 60.27 & 0.46 & 10.78 & 6.70 & 1770 & & & & \\
\hline $12 / 16 / 98$ & 12.00 & 2.00 & 10900 & & & & & 71.35 & 37.95 & 3700 & & & & & 18.08 & 9.20 & 2230 & & & & \\
\hline \begin{tabular}{|l|}
$12 / 29 / 98$ \\
\end{tabular} & 13.23 & 2.66 & 12700 & & 10.05 & 3.55 & 1.20 & 115.55 & 61.15 & 7280 & & & & & 43.46 & 24.07 & 6930 & & 31.71 & 25.54 & 3.97 \\
\hline $2 / 2 / 99$ & 12.49 & 2.08 & 12300 & & & & & 108.42 & 57.90 & 6010 & & & & & 40.37 & 21.30 & 6480 & & & & \\
\hline $3 / 9 / 99$ & & & & & & & & 76.78 & 38.16 & 2110 & & & & & & & & & & & \\
\hline $3 / 25 / 99$ & & & & & & & & 26.95 & 14.63 & 1870 & & 10.20 & 13.09 & nd & & & & & & & \\
\hline $5 / 24 / 99$ & 10.63 & 2.59 & 13100 & & 8.63 & 2.12 & 1.30 & & & & & & & & 25.29 & 16.22 & 8210 & & 18.87 & 14.48 & 3.87 \\
\hline $6 / 14 / 99$ & & & & & & & & 7.79 & 12.38 & 1880 & & 15.13 & 13.02 & nd & 8.19 & 7.41 & 1700 & & 5.29 & 4.31 & nd \\
\hline $6 / 15 / 99$ & & & & & & & & & & & & & & & & & & & & & \\
\hline $6 / 16 / 99$ & & & & & & & & & & & & & & & & & & & & & \\
\hline $6 / 17 / 99$ & & & & & & & & & & & & & & & & & & & & & \\
\hline $7 / 7 / 99$ & & & & & & & & 74.42 & 53.64 & 7740 & & & & & 28.27 & 15.83 & 8490 & & & & \\
\hline $7 / 19 / 99$ & 11.01 & 3.56 & 12100 & & 7.58 & 2.18 & 0.93 & & & & & & & & & & & & & & \\
\hline $8 / 26 / 99$ & & & & & & & & & & & & & & & & & & & & & \\
\hline $8 / 27 / 99$ & 9.36 & 1.84 & 6130 & & 7.38 & 1.66 & 0.14 & & & & & & & & & & & & & & \\
\hline $9 / 21 / 99$ & 11.80 & 3.15 & 12000 & & 8.56 & 1.95 & 0.95 & 62.33 & 48.34 & 5660 & & 50.95 & 44.20 & 0.76 & 23.60 & 12.38 & 6000 & & 13.44 & 10.56 & 2.16 \\
\hline $11 / 2 / 99$ & 10.34 & 3.11 & 12300 & & & & & 56.34 & 49.02 & 7050 & & & & & 25.57 & 14.43 & 9480 & & & & \\
\hline $1 / 4 / 00$ & & & & & & & & 50.61 & 38.75 & 6070 & & & & & 13.69 & \begin{tabular}{|c|}
9.04 \\
\end{tabular} & 26400 & 0.63 & & & \\
\hline $2 / 11 / 00$ & 8.58 & 4.80 & 12200 & 0.64 & & & & 44.33 & 41.04 & 8040 & 0.12 & & & & 9.41 & 11.38 & 10000 & 0.82 & & & \\
\hline $3 / 1 / 00$ & 5.45 & 5.59 & 12900 & 1.75 & & & & 42.29 & 39.79 & 7690 & 1.34 & & & & 11.20 & 12.93 & 9560 & 1.34 & & & \\
\hline $3 / 27 / 00$ & 5.31 & 5.43 & 12900 & 2.05 & & & & 41.02 & 36.88 & 8980 & 1.17 & & & & 10.23 & 11.68 & 11200 & 1.53 & & & \\
\hline
\end{tabular}

All concentrations in ppmv and normalized by $\mathrm{CO}_{2}$ levels.

Shaded values are from the B\&K. Non-shaded values are from gas chromatography analysis

nd $=$ not detected

italicized values were not used - low $\mathrm{CO}_{2}$ indicates non-representative sample 
WSRC-TR-2000-00182

\begin{tabular}{|c|c|c|c|c|c|c|c|c|c|c|c|c|c|c|c|c|c|c|c|c|c|}
\hline \multicolumn{5}{|c|}{ MLBB-008 } & \multicolumn{3}{|l|}{$\mathrm{GC}$} & \multicolumn{4}{|c|}{ MLBB-009 } & \multicolumn{3}{|l|}{ GC } & \multicolumn{4}{|c|}{ MLBB-010 } & \multicolumn{3}{|l|}{ GC } \\
\hline \begin{tabular}{|l|} 
Date \\
\end{tabular} & PCE & TCE & $\mathrm{CO} 2$ & FR113 & PCE & TCE & FR113 & PCE & TCE & $\mathrm{CO} 2$ & FR113 & PCE & TCE & FR113 & PCE & TCE & $\mathrm{CO} 2$ & FR113 & PCE & TCE & FR113 \\
\hline $10 / 14 / 97$ & 83.06 & 60.10 & 5750 & & & & & 105.81 & 78.58 & 12400 & & & & & 82.18 & 54.42 & 4410 & & & & \\
\hline $5 / 8 / 98$ & 98.40 & 66.80 & 6000 & & 78.30 & 61.58 & 0.94 & 75.73 & 61.07 & 12000 & & & & & 81.91 & 56.35 & 6900 & & & & \\
\hline $6 / 30 / 98$ & 93.01 & 58.09 & 8180 & & & & & 55.43 & 41.81 & 15500 & & & & & 83.74 & 54.31 & 8440 & & & & \\
\hline $8 / 10 / 98$ & 90.00 & 59.26 & 8080 & & & & & 53.86 & 42.04 & 16100 & & & & & 78.52 & 53.67 & 7580 & & & & \\
\hline $9 / 8 / 98$ & 91.76 & 57.93 & 7520 & & & & & 46.99 & 35.92 & 15900 & & & & & 68.14 & 46.72 & 9580 & & & & \\
\hline $11 / 24 / 98$ & 116.34 & 71.29 & 9190 & & 85.23 & 75.79 & 1.08 & 49.01 & 30.44 & 17400 & & & & & 107.00 & 70.24 & 9140 & & 45.60 & 37.30 & 2.26 \\
\hline $12 / 8 / 98$ & 105.07 & 60.93 & 9000 & & 69.07 & 60.65 & 0.85 & 48.00 & 31.30 & 16000 & & & & & 117.80 & 68.51 & 8180 & & & & \\
\hline $12 / 16 / 98$ & 102.15 & 61.53 & 9010 & & 79.50 & 69.64 & 1.00 & 43.64 & 28.40 & 16900 & & & & & 109.31 & 68.50 & 9320 & & 90.95 & 78.68 & 1.27 \\
\hline $12 / 29 / 98$ & 109.76 & 65.61 & 10900 & & & & & 42.20 & 26.50 & 16000 & & 28.86 & 29.26 & 4.89 & 73.95 & 46.44 & 12300 & & & & \\
\hline $2 / 2 / 99$ & 95.12 & 58.13 & 10900 & & & & & 38.76 & 24.45 & 16100 & & & & & 71.25 & 43.18 & 11200 & & & & \\
\hline $3 / 9 / 99$ & 96.33 & 57.24 & 9119 & & 101.33 & 59.48 & 1.32 & & & & & & & & & & & & & & \\
\hline $3 / 25 / 99$ & 57.24 & 38.79 & 9560 & & 41.79 & 40.97 & 0.88 & & & & & & & & 87.49 & 49.63 & 6940 & & 71.01 & 52.18 & 0.12 \\
\hline $5 / 24 / 99$ & 72.20 & 48.39 & 12300 & & & & & 27.50 & 19.54 & 16700 & & 18.37 & 18.16 & 4.27 & & & & & & & \\
\hline $6 / 14 / 99$ & 52.29 & 46.93 & 8720 & & 52.33 & 51.36 & 0.70 & 39.94 & 18.80 & 14300 & & 17.20 & \begin{tabular}{|l|}
16.17 \\
\end{tabular} & 4.71 & 95.58 & 65.87 & 6340 & & 92.18 & 75.35 & 0.79 \\
\hline $6 / 15 / 99$ & & & & & & & & & & & & & & & & & & & & & \\
\hline $6 / 16 / 99$ & & & & & & & & & & & & & & & & & & & & & \\
\hline $6 / 17 / 99$ & & & & & & & & & & & & & & & & & & & & & \\
\hline $7 / 7 / 99$ & 62.54 & 47.19 & 11800 & & & & & 38.52 & 18.85 & 15700 & & 13.94 & 14.56 & 3.06 & 42.72 & 27.55 & 12500 & & & & \\
\hline $7 / 19 / 99$ & & & & & & & & & & & & & & & & & & & & & \\
\hline $8 / 26 / 99$ & 49.14 & 42.74 & 10500 & & 40.01 & 38.99 & 0.85 & 28.07 & 21.61 & 17100 & & 17.63 & 18.13 & 1.99 & 63.05 & 44.59 & 6890 & & 47.63 & 37.50 & 0.77 \\
\hline $8 / 27 / 99$ & & & & & & & & & & & & & & & & & & & & & \\
\hline 9/21/99 & & & & & & & & & & & & & & & 44.39 & 27.82 & 11300 & & 27.98 & 23.48 & 2.17 \\
\hline $11 / 2 / 99$ & 55.26 & 44.42 & 11400 & & & & & 29.37 & 15.80 & 16400 & & & & & 27.87 & 17.57 & 12700 & & & & \\
\hline $1 / 4 / 00$ & 36.85 & 27.02 & 6350 & 0.25 & & & & 12.60 & 11.73 & 14600 & 1.10 & $7 \overline{7.67}$ & 9.08 & 3.99 & 29.89 & 18.86 & 11200 & $\overline{0.94}$ & & & \\
\hline $2 / 11 / 00$ & 40.64 & 36.45 & 10600 & 0.53 & & & & 11.95 & 11.29 & 14600 & 1.21 & & & & 16.87 & 14.26 & 13300 & 0.78 & & & \\
\hline $3 / 1 / 00$ & 32.97 & 29.22 & 9610 & 1.39 & & & & 10.70 & 12.72 & 15100 & 1.67 & & & & 20.76 & 16.95 & 12600 & 1.48 & & & \\
\hline $3 / 27 / 00$ & 36.42 & 31.10 & 11500 & 1.25 & & & & 8.99 & 10.88 & 14700 & 1.81 & & & & 13.62 & 12.09 & 14100 & 1.42 & & & \\
\hline
\end{tabular}

All concentrations in ppmv and normalized by $\mathrm{CO}_{2}$ levels.

Shaded values are from the B\&K. Non-shaded values are from gas chromatography analysis

nd $=$ not detected

italicized values were not used - low $\mathrm{CO}_{2}$ indicates non-representative sample 


\begin{tabular}{|c|c|c|c|c|c|c|c|c|c|c|c|c|c|c|c|c|c|c|c|c|c|}
\hline \multicolumn{5}{|c|}{ MLBB-011 } & \multicolumn{3}{|l|}{$G C$} & \multicolumn{4}{|c|}{ MLBB-012 } & \multicolumn{3}{|l|}{$G C$} & \multicolumn{4}{|c|}{ MLBB-013 } & \multicolumn{3}{|l|}{$G C$} \\
\hline Date & PCE & TCE & $\mathrm{CO} 2$ & FR113 & PCE & TCE & FR113 & PCE & TCE & $\mathrm{CO} 2$ & FR113 & PCE & TCE & FR113 & PCE & TCE & $\mathrm{CO} 2$ & FR113 & PCE & TCE & \begin{tabular}{|l|} 
FR113 \\
\end{tabular} \\
\hline 10/14/97 & \begin{tabular}{|l|}
29.78 \\
\end{tabular} & 21.60 & 11000 & & & & & 81.44 & 51.79 & 11700 & & & & & 5.42 & 2.58 & 10000 & & & & \\
\hline $5 / 8 / 98$ & \begin{tabular}{|l|}
19.12 \\
\end{tabular} & 14.44 & 12300 & & & & & 63.41 & \begin{tabular}{|l|}
38.64 \\
\end{tabular} & 10900 & & & & & 3.63 & 2.11 & 13300 & & & & \\
\hline 6/30/98 & \begin{tabular}{|l|}
16.36 \\
\end{tabular} & 11.45 & 15400 & & & & & 46.51 & \begin{tabular}{|l|}
27.16 \\
\end{tabular} & 12900 & & & & & 3.12 & 2.04 & 16900 & & & & \\
\hline $8 / 10 / 98$ & 16.38 & 11.62 & 15900 & & & & & \begin{tabular}{|l|}
43.73 \\
\end{tabular} & 25.73 & 13200 & & & & & 3.02 & 1.62 & 15900 & & & & \\
\hline 9/8/98 & 14.83 & 10.14 & 16100 & & & & & 44.78 & 25.16 & 13400 & & & & & 2.78 & 1.49 & 18000 & & & & \\
\hline 11/24/98 & \begin{tabular}{|l|}
21.78 \\
\end{tabular} & 10.01 & 15700 & & & & & 50.03 & 22.15 & 13000 & & & & & 1.49 & 0.84 & 10700 & & & & \\
\hline 12/8/98 & \begin{tabular}{|l|}
18.35 \\
\end{tabular} & 9.14 & 15500 & & & & & 50.64 & 24.91 & 13200 & & & & & 2.78 & 0.00 & 15900 & & & & \\
\hline 12/16/98 & \begin{tabular}{|l|}
18.69 \\
\end{tabular} & 8.77 & 15600 & & & & & 49.09 & 23.18 & 13200 & & 40.05 & 26.71 & 0.58 & 2.33 & 0.00 & 13900 & & & & \\
\hline 12/29/98 & 18.35 & 7.90 & 15500 & & 7.70 & \begin{tabular}{|l|l|}
5.74 \\
\end{tabular} & 4.85 & 52.18 & 23.27 & 13200 & & & & & 2.78 & 0.00 & 16700 & & 0.78 & 0.63 & 0.82 \\
\hline $2 / 2 / 99$ & 15.85 & 7.08 & 15600 & & & & & \begin{tabular}{|l|l|}
47.82 \\
\end{tabular} & 21.13 & 13400 & & & & & 2.64 & 0.00 & 17200 & & \begin{tabular}{|l|l|} 
& 0.90 \\
\end{tabular} & 0.66 & 0.78 \\
\hline $3 / 9 / 99$ & \begin{tabular}{|l|}
15.58 \\
\end{tabular} & 6.57 & 15400 & & 6.69 & 5.28 & 4.64 & & & & & & & & & & & & & & \\
\hline $3 / 25 / 99$ & & & & & & & & & & & & & & & & & & & & & \\
\hline $5 / 24 / 99$ & & & & & & & & 40.20 & 18.22 & 13700 & & 35.07 & 21.91 & 0.83 & & & & & & & \\
\hline $6 / 14 / 99$ & & & & & & & & & & & & & & & & & & & & & \\
\hline $6 / 15 / 99$ & \begin{tabular}{|l|}
21.49 \\
\end{tabular} & 6.45 & 15300 & & 4.56 & 3.54 & 4.06 & 36.65 & 20.12 & 13000 & & 28.86 & 17.01 & 0.78 & & & & & & & \\
\hline $6 / 16 / 99$ & & & & & & & & & & & & & & & 2.57 & 2.28 & 16300 & & \begin{tabular}{|l|l|} 
\\
\end{tabular} & 0.66 & 0.60 \\
\hline $6 / 17 / 99$ & & & & & & & & & & & & & & & & & & & & & \\
\hline $7 / 7 / 99$ & \begin{tabular}{|l|}
24.00 \\
\end{tabular} & 6.59 & 15800 & & \begin{tabular}{|l}
4.31 \\
\end{tabular} & 3.64 & 2.73 & 36.82 & 20.09 & 13200 & & 34.88 & 19.10 & 0.90 & & & & & & & \\
\hline $7 / 19 / 99$ & & & & & & & & & & & & & & & 3.12 & 1.68 & 17100 & & 0.52 & 0.51 & 0.55 \\
\hline $8 / 26 / 99$ & \begin{tabular}{|l|}
19.56 \\
\end{tabular} & 7.27 & 16200 & & 6.19 & \begin{tabular}{|l|l|}
4.77 \\
\end{tabular} & 2.86 & 30.71 & 16.25 & 12700 & & 23.15 & 13.76 & 0.72 & & & & & & & \\
\hline $8 / 27 / 99$ & & & & & & & & & & & & & & & 2.13 & 0.59 & 13100 & & 0.64 & 0.24 & 0.42 \\
\hline 9/21/99 & & & & & & & & & & & & & & & & & & & & & \\
\hline 11/2/99 & \begin{tabular}{|l|}
21.60 \\
\end{tabular} & 5.52 & 16500 & & & & & & & & & & & & & & & & & & \\
\hline 1/4/00 & 3.84 & 3.00 & 15700 & 2.27 & 1.88 & 2.75 & 4.04 & 28.10 & $\mid 12.00$ & 12000 & $\overline{0.53}$ & $\begin{array}{c}18.63 \\
\end{array}$ & \begin{tabular}{|l|l|}
11.36 \\
\end{tabular} & 1.05 & 0.93 & 1.97 & 16300 & 0.33 & & & \\
\hline $2 / 11 / 00$ & 4.57 & 4.01 & 15400 & 1.92 & & & & 24.96 & 14.40 & 12500 & 0.41 & & & & & 3.60 & 17300 & 0.53 & & & \\
\hline $3 / 1 / 00$ & 3.33 & 5.18 & 15800 & 2.21 & & & & 26.48 & 14.38 & 12100 & 0.91 & & & & 0.07 & 4.18 & 17900 & 1.34 & & & \\
\hline $3 / 27 / 00$ & 3.23 & 4.75 & 15500 & 2.06 & & & & 26.50 & \begin{tabular}{|l|}
13.77 \\
\end{tabular} & 11500 & 1.15 & & & & & 4.37 & 16000 & 1.46 & & & \\
\hline
\end{tabular}

All concentrations in ppmv and normalized by $\mathrm{CO}_{2}$ levels.

Shaded values are from the B\&K. Non-shaded values are from gas chromatography analysis

nd $=$ not detected

italicized values were not used - low $\mathrm{CO}_{2}$ indicates non-representative sample 
WSRC-TR-2000-00182

\begin{tabular}{|c|c|c|c|c|c|c|c|c|c|c|c|c|c|c|c|c|c|c|c|c|c|}
\hline \multicolumn{5}{|c|}{ MLBB-014 } & \multicolumn{3}{|l|}{ GC } & \multicolumn{4}{|c|}{ MLBB-015 } & \multicolumn{3}{|l|}{ GC } & \multicolumn{4}{|c|}{ MLBB-016 } & \multicolumn{3}{|l|}{ GC } \\
\hline \begin{tabular}{|l|} 
Date \\
\end{tabular} & PCE & TCE & $\mathrm{CO} 2$ & FR113 & PCE & TCE & FR113 & PCE & TCE & $\mathrm{CO} 2$ & FR113 & PCE & TCE & FR113 & PCE & TCE & $\mathrm{CO} 2$ & \begin{tabular}{|l|} 
FR113 \\
\end{tabular} & PCE & TCE & \begin{tabular}{|l|} 
FR113 \\
\end{tabular} \\
\hline $10 / 14 / 97$ & 11.49 & 5.76 & 11800 & & & & & & & & & & & & 17.42 & 12.58 & 10400 & & & & \\
\hline $5 / 8 / 98$ & 5.88 & 3.22 & 13000 & & & & & & & & & & & & 13.88 & 10.50 & 12800 & & & & \\
\hline 6/30/98 & 4.62 & 2.51 & 16700 & & & & & 15.38 & 9.39 & 10300 & & & & & 11.71 & 8.46 & 16600 & & & & \\
\hline 8/10/98 & 3.92 & 2.22 & 16700 & & & & & & & & & & & & 11.49 & 8.24 & 16600 & & & & \\
\hline $9 / 8 / 98$ & 3.95 & 1.94 & 17400 & & & & & 15.61 & 9.15 & 14300 & & & & & 11.16 & 7.72 & 17100 & & & & \\
\hline $11 / 24 / 98$ & 4.82 & \begin{tabular}{|l|}
0.19 \\
\end{tabular} & 15700 & & & & & 24.37 & 8.95 & 12900 & & & & & 13.63 & 5.37 & 16200 & & & & \\
\hline $12 / 8 / 98$ & 4.04 & 0.00 & 16500 & & & & & 18.26 & 7.70 & 13800 & & & & & 14.00 & 5.89 & 16200 & & & & \\
\hline 12/16/98 & 4.35 & 0.00 & 16400 & & & & & 19.45 & 7.50 & 13700 & & 17.25 & \begin{tabular}{|l|}
9.02 \\
\end{tabular} & 1.59 & 13.40 & 5.07 & 16300 & & & & \\
\hline \begin{tabular}{|l|}
$12 / 29 / 98$ \\
\end{tabular} & 3.97 & 0.00 & 16500 & & 2.21 & 1.14 & 0.62 & 17.78 & 6.58 & 13900 & & & & & 13.94 & 5.38 & 16100 & & 2.18 & 2.26 & 5.68 \\
\hline $2 / 2 / 99$ & 3.42 & 0.00 & 16900 & & 1.80 & 0.96 & 0.51 & 15.63 & 5.72 & 14200 & & & & & 12.80 & 4.78 & 16400 & & 2.27 & 2.20 & 5.09 \\
\hline $3 / 9 / 99$ & & & & & & & & 16.03 & 5.34 & 13700 & & 15.62 & 7.12 & 1.80 & & & & & & & \\
\hline $3 / 25 / 99$ & & & & & & & & & & & & & & & & & & & & & \\
\hline 5/24/99 & & & & & & & & 10.90 & 5.54 & 15300 & & 7.76 & \begin{tabular}{|l|}
4.53 \\
\end{tabular} & 1.65 & & & & & & & \\
\hline $6 / 14 / 99$ & & & & & & & & & & & & & & & & & & & & & \\
\hline $6 / 15 / 99$ & & & & & & & & 16.38 & 6.30 & 14800 & & 6.88 & 4.22 & 2.09 & 23.54 & 5.15 & 15700 & & 1.26 & 1.86 & 4.64 \\
\hline $6 / 16 / 99$ & 3.52 & 1.82 & 17100 & & 1.54 & \begin{tabular}{|l|}
0.81 \\
\end{tabular} & 0.49 & & & & & & & & & & & & & & \\
\hline $6 / 17 / 99$ & & & & & & & & & & & & & & & & & & & & & \\
\hline $7 / 7 / 99$ & & & & & & & & 14.61 & 5.50 & 15200 & & 7.29 & 4.09 & 1.87 & & & & & & & \\
\hline 7/19/99 & 3.39 & 1.63 & 17200 & & 1.44 & 0.91 & 0.42 & & & & & & & & 25.30 & 5.24 & 16600 & & 1.85 & 2.00 & 4.78 \\
\hline $8 / 26 / 99$ & & & & & & & & & & & & & & & 19.36 & 4.29 & 16800 & & 1.61 & 1.66 & 3.35 \\
\hline $8 / 27 / 99$ & 2.81 & 1.49 & 16400 & & 1.43 & 0.95 & 0.39 & 13.83 & 6.65 & 13800 & & 10.57 & 5.30 & 1.25 & & & & & & & \\
\hline $9 / 21 / 99$ & & & & & & & & & & & & & & & & & & & & & \\
\hline $11 / 2 / 99$ & & & & & & & & & & & & & & & & & & & & & \\
\hline 1/4/00 & & & & & & & & & & & & & & & 1.82 & 1.36 & 15000 & 2.36 & & & \\
\hline $2 / 11 / 00$ & 1.20 & 2.65 & 16600 & 0.05 & & & & 6.79 & 4.49 & 14500 & 0.54 & & & & 1.97 & 3.16 & 15900 & 2.17 & & & \\
\hline $3 / 1 / 00$ & 1.98 & 3.72 & 17100 & 0.62 & & & & 5.90 & 4.66 & 14900 & 1.08 & & & & 2.01 & 3.95 & 15900 & 2.67 & & & \\
\hline $3 / 27 / 00$ & 2.29 & 6.06 & 6710 & 1.53 & & & & 5.92 & 5.08 & 14800 & 1.21 & & & & 1.52 & 3.35 & 15900 & 2.64 & & & \\
\hline
\end{tabular}

All concentrations in ppmv and normalized by $\mathrm{CO}_{2}$ levels.

Shaded values are from the B\&K. Non-shaded values are from gas chromatography analysis

nd $=$ not detected

italicized values were not used - low $\mathrm{CO}_{2}$ indicates non-representative sample 
WSRC-TR-2000-00182

\begin{tabular}{|c|c|c|c|c|c|c|c|c|c|c|c|c|c|c|c|c|c|c|c|c|c|}
\hline \multicolumn{5}{|c|}{ MLBB-017 } & \multicolumn{3}{|l|}{$\mathrm{GC}$} & \multicolumn{4}{|c|}{ MLBB-018 } & \multicolumn{3}{|l|}{$\mathrm{GC}$} & \multicolumn{4}{|c|}{ MLBB-019 } & \multicolumn{3}{|l|}{ GC } \\
\hline Date & PCE & TCE & $\mathrm{CO} 2$ & FR113 & PCE & TCE & FR113 & PCE & TCE & $\mathrm{CO} 2$ & FR113 & PCE & TCE & FR113 & PCE & TCE & $\mathrm{CO} 2$ & \begin{tabular}{|l|} 
FR113 \\
\end{tabular} & PCE & TCE & FR113 \\
\hline $10 / 14 / 97$ & 24.81 & 17.77 & 10400 & & & & & 21.29 & 15.53 & 10200 & & & & & 9.95 & 2.81 & 1025 & & & & \\
\hline 5/8/98 & 18.09 & 12.74 & 13000 & & & & & 20.73 & 14.28 & 12100 & & & & & 12.20 & 6.58 & 12100 & & & & \\
\hline $6 / 30 / 98$ & 13.90 & 9.65 & 15800 & & & & & 15.70 & 10.71 & 14900 & & & & & 6.80 & 4.55 & 11100 & & & & \\
\hline $8 / 10 / 98$ & 12.25 & 8.67 & 14400 & & & & & 12.56 & 8.57 & 12800 & & & & & 4.91 & 3.49 & 6080 & & & & \\
\hline 9/8/98 & 12.15 & 8.42 & 16100 & & & & & 13.20 & 8.89 & 17000 & & & & & 6.45 & 3.31 & 5690 & & & & \\
\hline $11 / 24 / 98$ & 9.17 & 3.10 & 8740 & & & & & 6.97 & 1.75 & 10100 & & & & & 4.91 & 2.22 & 4860 & & & & \\
\hline 12/8/98 & 13.70 & 5.95 & 14100 & & & & & 12.43 & 5.16 & 14000 & & & & & 3.02 & 2.22 & 2540 & & & & \\
\hline $12 / 16 / 98$ & 11.11 & 4.08 & 12100 & & & & & 7.65 & 1.95 & 10400 & & & & & 6.17 & 0.84 & 10800 & & & & \\
\hline $12 / 29 / 98$ & 14.58 & 5.92 & 15800 & & 1.81 & 2.08 & 6.58 & 16.58 & 6.73 & 16500 & & 1.00 & 1.77 & 8.44 & 6.58 & 1.04 & 13200 & & & & \\
\hline $2 / 2 / 99$ & 13.54 & 5.46 & 15600 & & 1.79 & 2.22 & 5.95 & 16.10 & 6.82 & 16700 & & & & & 5.43 & 0.48 & 12000 & & & & \\
\hline 3/9/99 & & & & & & & & 10.84 & 3.67 & 12400 & & nd & 1.95 & 5.55 & & & & & & & \\
\hline $3 / 25 / 99$ & 100.47 & 35.72 & 1290 & & 14.70 & 20.37 & 44.84 & 10.08 & 3.53 & 12500 & & 0.61 & 1.50 & 5.05 & 4.53 & 0.15 & 12400 & & 1.87 & 1.51 & 0.76 \\
\hline $5 / 24 / 99$ & & & & & & & & & & & & & & & 4.57 & 2.21 & 14700 & & 3.08 & 1.87 & 0.97 \\
\hline $6 / 14 / 99$ & & & & & & & & & & & & & & & & & & & & & \\
\hline $6 / 15 / 99$ & 22.25 & 5.32 & 15100 & & 1.80 & 2.42 & 4.36 & & & & & & & & & & & & & & \\
\hline $6 / 16 / 99$ & & & & & & & & & & & & & & & & & & & & & \\
\hline $6 / 17 / 99$ & & & & & & & & 7.02 & 7.60 & 988 & & 5.08 & 7.69 & nd & 7.51 & 3.05 & 14500 & & 2.89 & 1.93 & 1.00 \\
\hline 7/7/99 & & & & & & & & & & & & & & & & & & & & & \\
\hline 7/19/99 & 20.73 & 4.75 & 14300 & & 1.19 & 1.93 & 3.78 & 15.09 & 3.41 & 9860 & & 0.38 & 1.11 & 2.91 & 7.98 & 2.76 & 14400 & & 2.34 & 1.84 & 1.11 \\
\hline $8 / 26 / 99$ & 14.75 & 3.39 & 10900 & & 2.37 & 1.39 & 2.31 & 6.93 & 0.85 & 4540 & & 0.19 & 0.37 & 1.40 & & & & & & & \\
\hline $8 / 27 / 99$ & & & & & & & & & & & & & & & 8.71 & 2.96 & 15300 & & 6.07 & 2.05 & 1.36 \\
\hline $9 / 21 / 99$ & & & & & & & & & & & & & & & & & & & & & \\
\hline $11 / 2 / 99$ & & & & & & & & & & & & & & & & & & & & & \\
\hline $1 / 4 / 00$ & & & & & & & & 2.10 & 1.54 & 11500 & 2.18 & & & & 2.06 & 1.00 & 12900 & 0.43 & & & \\
\hline $2 / 11 / 00$ & 5.53 & 3.50 & 14000 & 2.09 & & & & 3.90 & 3.17 & 15000 & 2.22 & & & & 5.65 & 2.86 & 11900 & 0.26 & & & \\
\hline $3 / 1 / 00$ & 2.98 & 4.92 & 14000 & 2.60 & & & & 1.43 & 4.29 & 14200 & 2.91 & & & & 2.93 & 4.92 & 10600 & 0.94 & & & \\
\hline $3 / 27 / 00$ & 2.33 & 4.96 & 14600 & 2.66 & & & & 1.76 & 3.96 & 15600 & 2.67 & & & & 2.29 & 3.86 & 12800 & 1.19 & & & \\
\hline
\end{tabular}

All concentrations in ppmv and normalized by $\mathrm{CO}_{2}$ levels.

Shaded values are from the B\&K. Non-shaded values are from gas chromatography analysis

nd $=$ not detected

italicized values were not used - low $\mathrm{CO}_{2}$ indicates non-representative sample 
WSRC-TR-2000-00182

\begin{tabular}{|c|c|c|c|c|c|c|c|c|c|c|c|c|c|c|}
\hline \multicolumn{5}{|c|}{ MLBB-020 } & \multicolumn{3}{|l|}{ GC } & \multicolumn{4}{|c|}{ MLBB-024 } & \multicolumn{3}{|l|}{$\mathrm{GC}$} \\
\hline Date & PCE & TCE & $\mathrm{CO} 2$ & FR113 & PCE & TCE & FR113 & PCE & TCE & $\mathrm{CO} 2$ & FR113 & PCE & TCE & FR113 \\
\hline $10 / 14 / 97$ & 4.02 & 3.68 & 1075 & & & & & & & & & & & \\
\hline $5 / 8 / 98$ & 3.66 & 1.19 & 14100 & & & & & & & & & & & \\
\hline 6/30/98 & 2.28 & 1.05 & 15500 & & & & & & & & & & & \\
\hline 8/10/98 & 1.95 & 0.96 & 14200 & & & & & & & & & & & \\
\hline 9/8/98 & 2.37 & 0.86 & 14900 & & & & & & & & & & & \\
\hline $11 / 24 / 98$ & 1.30 & 0.00 & 11700 & & & & & & & & & & & \\
\hline 12/8/98 & 0.73 & 1.61 & 2300 & & & & & & & & & & & \\
\hline $12 / 16 / 98$ & 1.64 & 0.00 & 10900 & & & & & & & & & & & \\
\hline $12 / 29 / 98$ & 1.72 & 0.00 & 15100 & & & & & & & & & & & \\
\hline $2 / 2 / 99$ & 1.58 & 0.00 & 13800 & & & & & & & & & & & \\
\hline $3 / 9 / 99$ & & & & & & & & & & & & & & \\
\hline $3 / 25 / 99$ & & & & & & & & & & & & & & \\
\hline $5 / 24 / 99$ & 1.77 & 0.72 & 21700 & & 0.62 & \begin{tabular}{|l}
0.38 \\
\end{tabular} & 0.69 & & & & & & & \\
\hline $6 / 14 / 99$ & & & & & & & & & & & & & & \\
\hline $6 / 15 / 99$ & & & & & & & & & & & & & & \\
\hline 6/16/99 & & & & & & & & & & & & & & \\
\hline 6/17/99 & 3.93 & 1.19 & 20200 & & 0.64 & 0.36 & 0.59 & & & & & & & \\
\hline $7 / 7 / 99$ & & & & & & & & & & & & & & \\
\hline 7/19/99 & 3.84 & 1.16 & 20700 & & 0.66 & 0.40 & 0.72 & & & & & & & \\
\hline $8 / 26 / 99$ & & & & & & & & & & & & & & \\
\hline $8 / 27 / 99$ & 3.50 & 1.03 & 19800 & & 0.62 & nd & nd & & & & & & & \\
\hline 9/21/99 & & & & & & & & & & & & & & \\
\hline 11/2/99 & & & & & & & & & & & & & & \\
\hline $1 / 4 / 00$ & 1.32 & 0.48 & 19600 & 0.00 & & & & & & & & & & \\
\hline $2 / 11 / 00$ & 0.09 & 1.97 & 19700 & 0.00 & & & & & & & & & & \\
\hline $3 / 1 / 00$ & 1.54 & 2.71 & 20000 & 0.47 & & & & & & & & & & \\
\hline $3 / 27 / 00$ & 0.87 & 2.41 & 20300 & 0.79 & & & & 2.77 & 4.67 & 11900 & 0.47 & & & \\
\hline
\end{tabular}

All concentrations in ppmv and normalized by $\mathrm{CO}_{2}$ levels.

Shaded values are from the B\&K. Non-shaded values are from gas chromatography analysis $\mathrm{nd}=$ not detected

italicized values were not used - low $\mathrm{CO}_{2}$ indicates non-representative sample 


\section{APPENDIX B - CPT Logs}
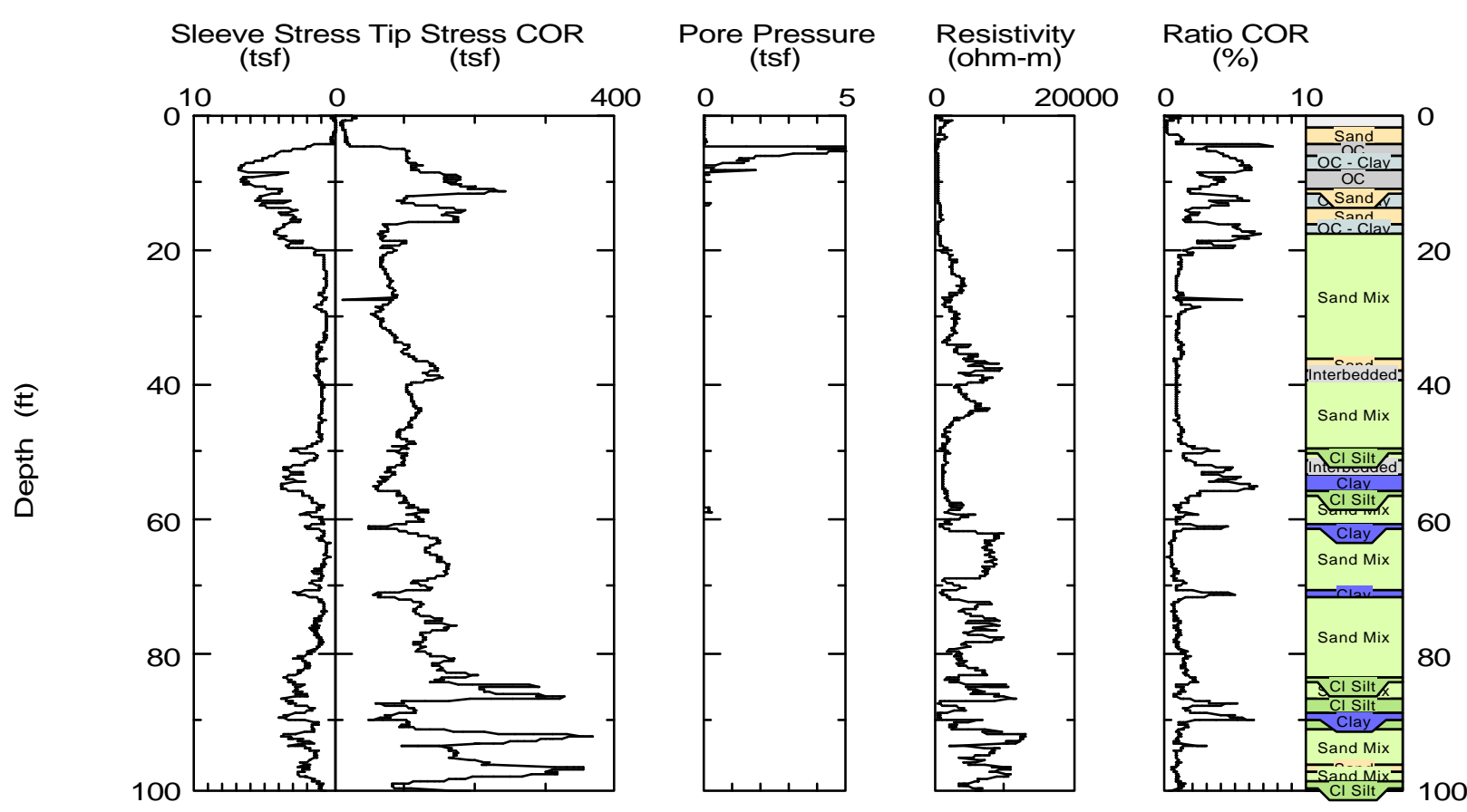

MLBB-022 CPT Log 


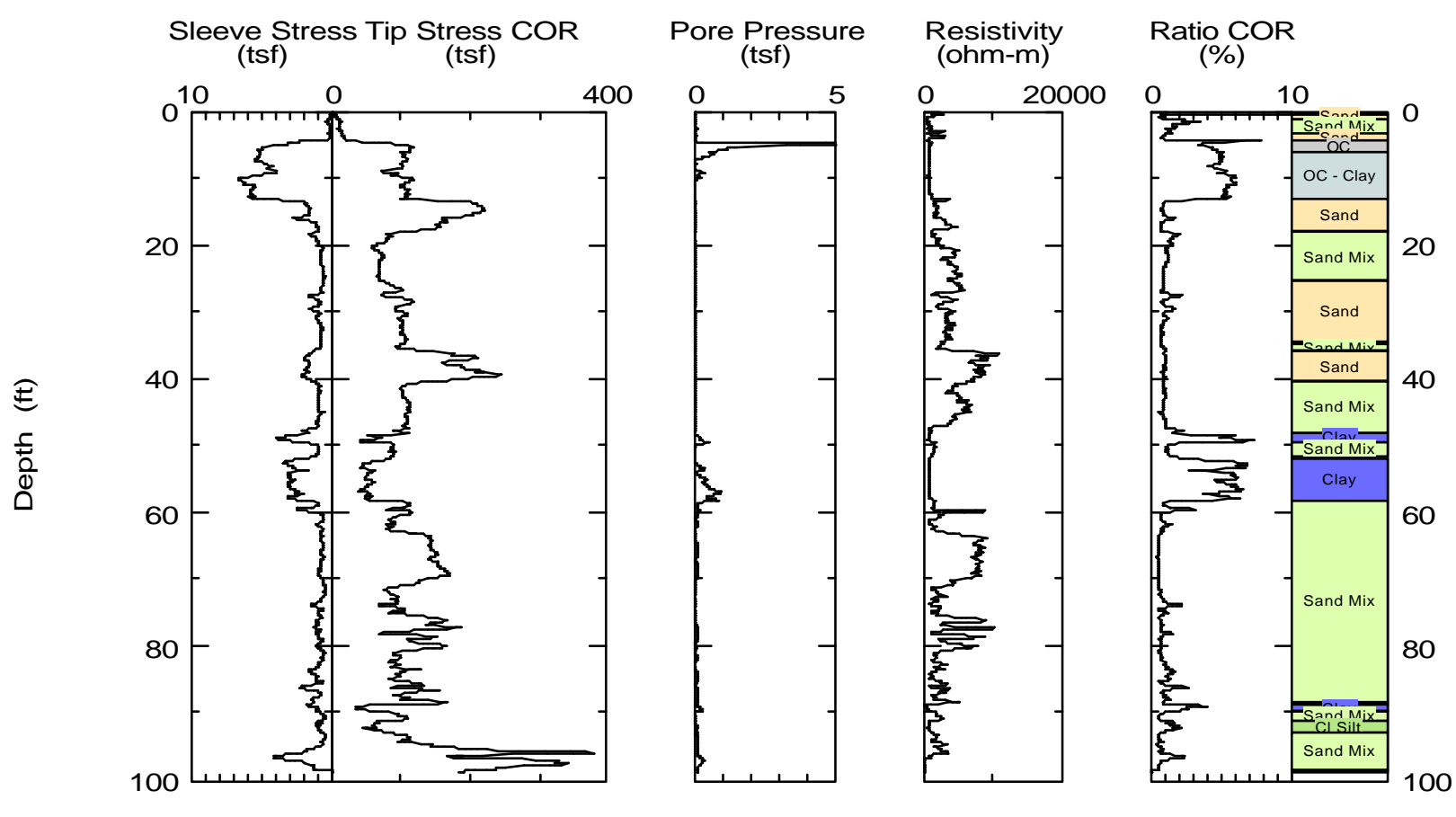

MLBB-023 CPT Log 


\section{APPENDIX C - Well and CPT Boring Coordinates}

\begin{tabular}{|l|r|r|}
\hline Well ID & Easting & Northing \\
\hline MLBB-001 & 50675 & 104777 \\
\hline MLBB-002 & 50671.75 & 104687.5 \\
\hline MLBB-003 & 50674 & 104907 \\
\hline MLBB-004 & 50851.39 & 104935.4 \\
\hline MLBB-006 & 50764.68 & 104753.1 \\
\hline MLBB-007 & 50847.57 & 104693.3 \\
\hline MLBB-008 & 50850.04 & 104746.6 \\
\hline MLBB-009 & 50910 & 104689 \\
\hline MLBB-010 & 50904.78 & 104753.9 \\
\hline MLBB-011 & 51005 & 104708 \\
\hline MLBB-012 & 51006 & 104758 \\
\hline MLBB-013 & 51040.5 & 104969.1 \\
\hline MLBB-014 & 51034 & 104906 \\
\hline MLBB-015 & 51040 & 104800 \\
\hline MLBB-016 & 51044.75 & 104673 \\
\hline MLBB-017 & 51046 & 104570 \\
\hline MLBB-018 & 51086 & 104507 \\
\hline MLBB-019 & 51111 & 104807 \\
\hline MLBB-020 & 51117 & 104991 \\
\hline MLBB-021 & 50613.6 & 104817.3 \\
\hline MLBB-022 ${ }^{*}$ & 51290.7 & 104680.2 \\
\hline MLBB-023* & 50866.6 & 104629.6 \\
\hline${ }^{*}$ CPT B01ngs $-n 0 t w s$ & \\
\hline
\end{tabular}

${ }^{*}$ CPT Borings - not wells 